\title{
Ortaokul Matematik Öğretmenlerinin Uzaktan Eğitimde Matematik Öğretim Deneyimleri
}

\author{
Secondary Mathematics Teachers' Mathematics Teaching Experiences in \\ Distance Education
}

\author{
Gülşah ÖZDEMiR BAKi ，Dr. Öğr. Üyesi, Atatürk Üniversitesi, Oltu Beşerî ve Sosyal Bilimler Fakültesi, \\ Erzurum/TÜRKIYE, gulsah.baki@atauni.edu.tr
}

Elif ÇELIK , Dr., Erzurum Milli Eğitim Müdürlüğü, Erzurum/TÜRKiYE, elif-aktepe2010@hotmail.com

\begin{abstract}
Özdemir Baki, G. ve Çelik, E. (2021). Ortaokul matematik öğretmenlerinin uzaktan eğitimde matematik öğretim deneyimleri. Batı Anadolu Eğitim Bilimleri Dergisi, 12 (1), 293-320.
\end{abstract}

Öz. Covid-19 pandemisi sadece sağıık alanında değil birçok alanda etkilerini göstermeye devam etmektedir. Bu alanlardan biri de eğitimdir. Pandeminin hızlı bir şekilde yayılması sebebiyle birçok ülkede olduğu gibi Türkiye de eğitim sürecine uzaktan eğitim yoluyla devam etmektedir. Bu çalışma, Covid-19 nedeniyle ilk defa uzaktan eğitim süreciyle karşı karşıya gelen ortaokul matematik öğretmenlerinin bahar döneminde ne tür sorunlar yaşadıklarını ve bu sorunları çözmek için güz döneminde ne tür tedbirler aldıklarıı, hangi yöntem ve teknikleri kullanmaya başladıklarını, başarıı bir ders için ne tür öğretimsel içerikler hazırladıklarını belirlemeyi amaçlamaktadır. Bu nedenle çalışma, nitel araştırma türlerinden biri olan fenomenolojik araştırma yaklaşımı çerçevesinde tasarlanmıştır. Çalışma, Türkiye'nin farkı bölgelerinde devlet ve özel okullarda görev yapan 25 ortaokul matematik öğretmeniyle yürütülmüştür. Katılımcıların belirlenmesinde kırsal, varoş ve kent merkezinde görev yapan öğretmenlere ulaşılarak maksimum çeşitlilik sağlanmaya çalışılmıştır. Katılımcı öğretmenlerin deneyimleriyle ilgili kapsamlı bilgi elde etmek amacıyla yarı yapılandırılmış görüşme tekniği kullanılmıştır. Elde edilen verilerin incelenmesinde içerik analizi tekniği kullanılmıştır. Yapılan analizler sonucunda öğretmenlerin uzaktan eğitim sürecinde öğretim elemanları (öğrenci, öğretmen ve matematiğe özgü), teknoloji ve dış faktör kaynaklı zorluklar yaşadıkları belirlenmiştir. Öğretmenlerin bu zorlukların üstesinden gelebilmek için öğretici tedbirleri kapsamında teknolojiyi takip etme ve kullanma, doküman/materyal eksikliğini giderme, öğrencinin aktif katılımını sağlama, ders süresini etkin kullanma ve iletişim yollarını artırma şeklinde önlemler aldıkları görülmüştür. Elde edilen bulgular, varoş ve kırsal bölgelerde görev yapan öğretmenler ile kent merkezinde görev yapan öğretmenlerin uzaktan eğitim sürecinde karşılaştıkları sorunlara bağlı olarak aldıkları tedbirlerin de farklılaşıı̆ını ortaya koymaktadır. Bu durum, eğitimde fırsat eşitsizliğinin uzaktan eğitim sürecine yansıması olarak değerlendirilebilir.

Anahtar Kelimeler: Uzaktan eğitim, Matematik öğretimi, Matematik öğretmenleri, Fenomenoloji.

\begin{abstract}
Covid-19 pandemic continues to show its effects not only in health but also in many areas. One of these areas is education. Due to the rapid spread of the pandemic as well as in many countries, Turkey is continuing the education process through distance education. This study aims to determine what kind of problems secondary mathematics teachers face in the spring semester of distance education and what kind of precaution they take in the fall semester to solve these problems. Therefore, the study was designed within the framework of phenomenological research approach. The research was carried out with 25 secondary mathematics teachers working in different regions of Turkey. In determining the participants, maximum diversity was tried to be
\end{abstract}


achieved by reaching the teachers working in rural, suburban and city centers. The interview technique was used to obtain comprehensive information about the experiences of the participating teachers. The obtained data were subjected to content analysis. The analyzes revealed that teachers had difficulties in distance education due to teaching elements, technology and external factors. In order to overcome these difficulties, it was observed that teachers took measures such as following and using technology, eliminating the lack of document/material, ensuring active participation of the student, using the lesson time effectively, and increasing the means of communication. As a result, it can be said that the measures taken by teachers working in suburbs and rural areas and those working in the city center differ depending on the problems they face in the distance education.

Keywords: Distance education, Mathematics education, Mathematics teachers, Phenomenology. 


\section{Extended Abstract}

Introduction. The Covid-19 epidemic, which has become a global pandemic, has its effects not only in the field of health but also in the economy, education and social fields. The rapid spread of Covid-19 has caused social concerns and concerns in many countries of the world. Therefore, many countries have temporarily suspended face-to-face education and accelerated distance education activities. In order to provide an effective education and training, Turkey, as in most countries, adopts the use of digital technology and carries out the distance education. The focus of most of the studies in distance education has been more on interaction (student-content, student-teacher, student-student). However, there are also studies examining the opinions of students and teachers on distance education. Although studies have been carried out to determine the opinions of teachers during the pandemic process, there are few studies in which teachers' distance education experiences and professional development are investigated in depth. In addition, the studies carried out were generally carried out in the first period when educational institutions switched to distance education and mostly reveal the problems experienced by teachers. The current study aims to determine what kind of measures secondary mathematics teachers take in the fall semester of the 2020-2021 academic year to solve the problems they encounter in the spring semester of the 2019-2020 academic year, and what kind of methods and techniques they use for a successful course. Considering the necessity of conducting mathematics lessons in an interactive way, it is remarkable how teachers make the distance mathematics teaching process more efficient. In line with this view, the main problem and sub-problems of the study are as follows:

* What is the mathematics teaching experience of secondary school mathematics teachers in distance education?

$>$ What are the difficulties faced by teachers while conducting live classes in the spring semester of the 2019-2020 academic year?

$>$ What kind of precaution did teachers take in the fall semester of the 2020-2021 academic year regarding the difficulties they faced?

$>$ What are the mathematics teaching materials and programs they use in the distance education?

What are the mathematics teaching methods and techniques used in the distance education?

Method. This study is designed within the framework of phenomenological research approach. The study was conducted with 25 secondary mathematics teachers working in public and private schools in different regions of Turkey. In determining the participants, maximum diversity was tried to be achieved by reaching the teachers working in rural, suburban and city centers. Semi-structured interviews were conducted online with the participating teachers. Content analysis technique was used in the analysis of the obtained data, and the findings were supported by giving the opinions of the participant teachers directly.

Results. As a result of the analysis, it was determined that teachers have difficulties in distance education due to elements of teaching (student, teacher, mathematics-specific), technology and external factors. It was determined from the opinions of teachers about the difficulties they experience in distance education that they mostly have internet problems. However, it has been determined that teachers working in suburb and rural schools are more faced with lack of infrastructure and lack of equipment. It has been determined that most of the teachers have difficulties in teaching mathematics via computer, using mathematical representations and performing operations, specific to mathematical content in distance education. In order to overcome these difficulties, it was observed that teachers took measures such as following and using technology, eliminating the lack of document, ensuring active participation of the student, using the lesson time effectively, and increasing the means of communication. It has been observed that teachers especially take graphic tablets to do mathematical operations easily. In the fall semester of distance education, it was determined that 
teachers participating in the research started using educational animations and videos, prepared worksheets, provided resource books, prepared topic summaries, and received cognitive training materials. In this context, the teachers monitored whether the student attended the lesson or not, asked the students to solve the problems themselves in their notebooks and keep a lesson note, and they made the students explain their operations and answers verbally.

Discussion and Conclusion. As a result of the study, it was revealed that teachers who mostly work in suburb and rural areas have internet problems. The reason for this is that the socio-economic status of the parents of the students is not sufficient. Moreover, the internet shortage prevented them from walking their synchronous lessons. However, it was observed that teachers working in these regions had more problems in communicating with students and parents than teachers working in the central school. While teachers in the city center tried to increase the number and variety of materials, they use in order to make synchronous lessons more efficient in the fall semester of distance education, teachers working in rural and suburban schools made an effort to increase the participation of students in class by solving the internet problem. This situation can be evaluated as the reflection of the inequality of opportunity in education to the distance education. 


\section{Giriş}

Küresel bir pandemi haline gelen Covid-19 salgını, sadece sağılık alanında değil ekonomi, eğitim ve sosyal alanlarda da etkilerini göstermektedir. Aralık 2019 tarihinde Çin'in Wuhan kentinde ilk kez görülen Covid-19'un hızlı bir şekilde yayılması, birçok dünya ülkesinde toplumsal kaygıların ve endişelerin yaşanmasına neden olmuştur (Lin, 2020; Üstün ve Özçiftçi, 2020). Dolayısıyla birçok ülke yüz yüze eğitime geçici bir süre ara vermiş ve uzaktan eğitim faaliyetlerini hızlandırmıştır. Hemen hemen her ülkede eğitim kurumları tarafından öğrenciler ve velilerle iletişimi sağlamak için mevcut uygulamaların yanı sıra canlı ders ve online kurslar yürütülmeye başlanmıştır (Chang ve Satako, 2020). Bu süreçte Türkiye'de ilkokul, ortaokul ve liseler 16 Mart 2020 tarihinden itibaren bir hafta tatil edilmiş ve 23 Mart 2020 tarihi itibariyle de uzaktan eğitime geçilerek TRT EBA TV kanalları ve Eğitim Bilişim Ağı (EBA) aracılı̆̆ıyla öğretim faaliyetleri sürdürülmüştür. Sadece TV kanallarıyla sınırlı kalınmayıp aynı zamanda öğretmenlerin ve öğrencilerin eş zamanlı olarak etkileşime girdikleri senkron eğitim imkanları da artırılmıştır. Böylece etkili bir eğitim ve öğretimin sağlanabilmesi amacıyla çoğu ülkede olduğu gibi Türkiye de dijital teknoloji kullanımını benimseyerek uzaktan eğitim sürecini yürütmektedir.

Eğitimde bilişim teknolojilerinin kullanılmasıyla birlikte yeni bir eğitim modelinin ortaya çıktığını belirten İşman (2011), bu yeni eğitim modelinin uzaktan eğitim olduğunu ifade etmektedir. Moore ve Kearsley (2011) uzaktan eğitimi, öğrenen ve öğreticilerin farklı ortamlarda bulunduğu, özel öğretim tasarımlarını ve teknolojilerini gerektiren planlanmış, açık erişimli öğretme ve öğrenme şekli olarak tanımlamaktadır. Schlosser ve Simonson'a (2009) göre uzaktan eğitim, öğrenme grubunun ayrıldığı ve öğrenenleri, öğretim kaynaklarını ve öğreticileri birbirine bağlamak için etkileşimli iletişim sistemlerinin kullanıldığı kurum tabanlı, örgün bir eğitimdir. Uzaktan eğitimin fırsat eşitsizliğine yönelik çözüm sağladığını belirten Kaya (2006) ise uzaktan eğitimi bireylerin eğitim teknolojilerini kullanarak daha çok kendi kendilerine öğrenmelerini temel alan bir disiplin olarak görmektedir. Bu tanımlardan yola çıkarak uzaktan eğitimin iletişim teknolojilerinin sunduğu fırsatlar doğrultusunda gerçekleştiğini söylemek doğru olacaktır. Bu açıdan bakıldığında, günümüz koşullarında dijital iletişim olanaklarının artması, uzaktan eğitim faaliyetlerinin daha çok internet tabanlı yürütülmesinde etkili olmaktadır. Dolayısıyla planlanan eğitim intiyaçları doğrultusunda uzaktan eğitim faaliyetleri senkron (eş zamanlı) veya asenkron (eş zamanlı olmayan) olarak gerçekleşmektedir (Romiszowski, 2004; Smith ve Dillon, 1999). Senkron uzaktan eğitim modelinde, öğretici ve öğrenenler farklı ortamlarda bulunmalarına rağmen aynı anda çevrimiçi olur ve derse katııılar. Dersler canlı ve gerçek zamanlı yürütülür. Öğretici ve öğrenenler çeşitli web tabanlı programlarla sesli ve görüntülü iletişim kurabilir ve paylaşımlarda bulunabilirler. Dolayısıyla senkron modelde etkileşimli bir öğrenme ortamı söz konusudur. Asenkron uzaktan eğitim modelinde ise öğrenciler kendilerine en uygun zamanda çevrimiçi olur ve öğretimsel içeriklere web tabanlı programlar aracılığıyla erişebilirler. Böylece öğrenciler bu içerikleri bireysel olarak okuyarak, dinleyerek, izleyerek öğrenme faaliyetlerini yürütebilirler.

Uzaktan eğitim ile ilgili araştırmalara bakıldığında, çoğu çalışmanın odak noktasının etkileşim olduğu görülmektedir (ör. Billings, Connors ve Skiba, 2001; Dennen, Darabi ve Smith, 2007; Hillman, Willis ve Gunawardena, 1994; Jansen ve Lewis, 1996; Kearsley, 1995). Uzaktan eğitim için Moore (1989) üç tür etkileşim tanımlamıştır: Öğrenci-içerik, öğrenci-öğretici ve öğrenci-öğrenci etkileşimi. Öğrenciler ve öğretici arasında ortaya çıkan etkileşim, öğrencilerin ders içeriğini anlamasına yardımcı olmayı amaçlamaktadır (Thurmond ve Wambach, 2004). Öğreticilerle etkileşim halinde olmak, öğrencilerin belirsizlik yaşadıkları durumları netleştirmelerine ve bilgilerini pekiştirmelerine de yardımcı olabilir. Öğrenci-öğrenci etkileşimi, ders içeriğini anlamayı ve eleştirel düşünmeyi teşvik etmeyi amaçlamaktadır. Özellikle bu yönde işbirlikçi projelerin yürütülmesi, öğrencilerin web tabanlı bir sınıf ortamına ait olma duygusunu geliştirebilir (Palloff ve Pratt, 2001). Öğrenci-içerik etkileşimi ise öğrencinin anlayışında, bakış açısında veya öğrenci zihninin bilişsel yapılarında değişikliklere neden 
olan, içerikle entelektüel olarak etkileşime girmesidir (Moore, 1989). Bu yönde farklı etkileşim türleri kullanılarak yüksek düzeyde bir etkileşimin sağlanması, öğrenme-öğretme sürecinin kalitesini artırmada etkili olacaktır.

Etkileşimli bir uzaktan eğitim sürecinin yürütülmesinde öğrenci ve öğretici rollerinin iyi tanımlanması gerekir. Türkiye de gerçek anlamda uzaktan eğitim uygulamalarının 1980'li yıllardan itibaren yürütülmesiyle (Cabı ve Ersoy, 2017; Demir, 2014) birlikte öğretici rolleri de şekillenmeye başlamıştır (Karaman ve Karabey, 2020). Yüz yüze eğitimde olduğu gibi uzaktan eğitim sürecinde de öğreticilerin etkili bir öğrenme ortamı hazırlamada büyük sorumlulukları vardır (Lehman ve Conceição, 2010; Dougiamas, 2000). Ancak uzaktan eğitimde öğretici rolleri yüz yüze öğretim yapılan sınıf ortamlarından farklılık göstermektedir. Berge (1995) başarılı bir çevrimiçi ders için öğreticinin rollerini; pedagojik, sosyal, yönetimsel ve teknik olmak üzere dört alanda sınıflandırmıştır. Berge'ye (1995) göre öğreticinin pedagojik rolleri; öğrencilerin kritik kavramları, ilkeleri ve becerileri anlaması için eğitim sürecinin kolaylaştırmaya yönelik görevleri üstlenmesidir. Bu tür görevler, öğrencileri bilgiyi yapılandırmalarını ve paylaşımda bulunmalarını teşvik etmeyi, etkileşimli öğrenme deneyimlerini tasarlamayı, öğrenme materyallerini iyileştirmeyi, geri bildirim vermeyi, ölçme değerlendirme bilgilerini takip etmeyi ve akran etkileşimini kolaylaştırmayı içerir. Öğreticinin sosyal rolleri, öğrencilerin bilişsel öğrenme süreçlerini desteklemek için çevrimiçi öğrenme topluluğu oluşturması ve sosyal ilişkiler kurmasıdır. Öğreticinin yönetimsel rolleri, öğrenme ortamı ile ilgili organizatör, planlayıcı ve oturum yöneticisi görevlerini içermektedir. Çevrimiçi öğreticinin teknik rolü ise öğrencilerin kullanılan sistem ve yazılım programına yönelik karşılaştığı sorunları belirlemesi ve öğrencileri teknik destek kaynaklarına yönlendirmesidir.

Uzaktan eğitimde çoğu araştırmanın odak noktası etkileşim (öğrenci-içerik, öğrenci-öğretici, öğrenci-öğrenci) olmasına rağmen uzaktan eğitim sürecine ilişkin öğrenci ve öğretici görüşlerinin incelendiği çalışmalara da rastlanmaktadır (Ağır, 2007; Bakioğlu ve Çevik, 2020; Barış ve Çankaya, 2016; Bayburtlu, 2020; Gürer, Tekinarslan ve Yavuzalp, 2016; Osmanoğlu, 2020; Şahin İzmirli ve Mısırlı, 2018). Bu yönde Şahin İzmirli ve Mısırlı (2018) bir devlet üniversitesinin eğitim fakültesinde görev yapan öğretim elemanlarının uzaktan eğitime ilişkin görüşlerini incelemişlerdir. Çalışmada elde edilen veriler olumlu (örn. erişim kolaylığı, çağın gerekliliği) ve olumsuz metafor (örn. etkileşim eksikliği ve yetersizliği) grupları olarak sınıflandırılmıştır. Gürer vd. (2016) ise çevrimiçi uzaktan eğitim aracılığıyla ortak zorunlu ders veren öğretim elemanlarının uzaktan eğitim süreciyle ilgili olumlu ve olumsuz görüşlerini incelemiş ve sistemin iyileştirilmesine yönelik öneriler sunmuşlardır. Benzer bir çalışma Barış ve Çankaya (2016) tarafından yapılmıştır. Araştırmalarında uzaktan eğitim dersleri veren öğretim elemanlarının sözel ve teorik derslerin uzaktan eğitim ile yürütülebileceği ancak uygulamalı ve etkileşim gerektiren derslerin uzaktan eğitim ile yürütülemeyeceği görüşünde olduklarını ifade etmişlerdir. Özel ve devlet okullarında görev yapan ilköğretim öğretmenlerin uzaktan eğitime yönelik tutumlarını belirlenmeye çalışan Ağır (2007) ise öğretmenlerin uzaktan eğitim teknolojilerine ilişkin görüşlerini incelemiştir. Dolayısıyla Covid-19 salgınından önce yapılan uzaktan eğitim araştırmalarının daha çok öğretim elemanlarının görüşlerini belirlemeye yönelik olduğu söylenebilir. Nitekim pandemi döneminde tüm eğitim kademelerinde uzaktan eğitime geçilmesiyle birlikte öğretmenlerin görüşleri de ön plana çıkmıştır. Bunun sonucu olarak pandemi döneminde branş öğretmenlerinin uzaktan eğitim deneyimlerini ortaya koyan çalışmalar yürütülmeye başlanmıştır. Örneğin, Bakioğlu ve Çevik (2020) uzaktan eğitimde ortaokul fen bilimleri öğretmenlerinin yaşadıkları deneyimleri belirlemeyi amaçlamışlardır. Bu amaçla çalışmada Türkiye'nin farklı bölgelerinde görev yapan fen bilimleri öğretmenlerinin uzaktan eğitimde yaşadıkları sorunlar tespit edilmiştir. Çalışma sonucunda öğretmenlerin uzaktan eğitim sürecinde teknoloji kullanımlarının ve mesleki gelişimlerinin olumlu yönde etkilendiğini belirlenmiştir. Kilit ve Güner (2021) ise matematik derslerinde web tabanlı uzaktan eğitime ilişkin matematik öğretmenlerinin görüşlerini incelemişlerdir. Web tabanlı uzaktan eğitimin avantaj ve dezavantajlarının belirlendiği çalışmada matematik öğretmenlerinin çoğunlukla web tabanlı uzaktan eğitimin matematik öğretimi için etkili ve verimli olmadığı görüşünde oldukları ortaya çıkmıştır. 
Pandemi sürecinde öğretmenlerin görüşlerini belirlemeye yönelik çalışmalar yürütülmüş olmasına rağmen öğretmenlerin uzaktan eğitim deneyimlerinin ve mesleki gelişimlerinin derinlemesine araştırıldığı az sayıda çalışma bulunmaktadır. Ayrıca yapılan çalışmalar genellikle eğitim kurumlarının uzaktan eğitime geçtikleri ilk dönemde gerçekleştirilmiş olup daha çok öğretmenlerin yaşadıkları sorunları ortaya koymaktadır. Mevcut çalışma ise ortaokul matematik öğretmenlerinin 2019-2020 eğitim-öğretim yılı bahar döneminde yaşadıkları sorunları çözmek için 2020-2021 eğitimöğretim yılı güz döneminde ne tür tedbirler aldıklarını, hangi yöntem ve teknikleri kullanmaya başladıklarını, başarıı bir ders için ne tür öğretimsel içerikler hazırladıklarını belirlemeyi amaçlamaktadır. Özellikle matematik derslerinin etkileşimli bir şekilde yürütülmesi gerekliliği dikkate alındığında, öğretmenlerin uzaktan matematik öğretim sürecini nasıl daha verimli hale getirdikleri dikkate değerdir. Bu görüş doğrultusunda çalışmanın ana problemi ve alt problemleri şu şekildedir:

* Ortaokul matematik öğretmenlerinin uzaktan eğitimde matematik öğretim deneyimleri nasıldır?

> Öğretmenlerin 2019-2020 eğitim öğretim yılının bahar döneminde canlı derslerini yürütürken karşılaştıkları zorluklar nelerdir?

$>$ Öğretmenler karşılaştıkları zorluklara yönelik 2020-2021 eğitim öğretim yılının güz döneminde ne tür önlemler almışlardır?

> Uzaktan eğitim sürecinde (bahar ve güz döneminde) kullandıkları matematik öğretim materyalleri ve programları nelerdir?

$>$ Uzaktan eğitim sürecinde (bahar ve güz döneminde) kullandıkları matematik öğretim yöntem ve teknikleri nelerdir?

\section{Yöntem}

Bu çalışma, ortaokul matematik öğretmenlerinin uzaktan matematik öğretim deneyimlerini derinlemesine incelemeyi amaçladığı için fenomenolojik araştırma yaklaşımı çerçevesinde tasarlanmıştır. Nitel araştırma türlerinden biri olan fenomenolojik araştırma, bireylerin yaşanmış deneyimlerinin özlerini aramaya odaklanır (Moustakas, 1994). Bu anlamda, bir fenomen ve kavramla ilgili yaşanmış deneyimlerin ortak anlamını keşfetmek için öznel deneyimleri irdeler. Dolayısıyla fenomenolojik araştırmaların temel amacı, bireylerin belli bir fenomene ilişkin deneyimlerinin neler olduğunu ve bu deneyimleri nasıl anlamlandırdıklarını ortaya çıkarmaktır (Creswell, 2013). Bu bakış açısı altında, öğretmenlerin uzaktan eğitimde matematik öğretimine yönelik deneyimlerinin neler olduğunu ve bu deneyimlerine ne tür anlamlar yüklediklerini ortaya koyabilmek için fenomonolojik araştırma yöntemi uygun görülmüştür.

\section{Çalışma Grubu}

Çalışma 2020 yılında Türkiye'nin farklı illerindeki devlet ve özel okullarda görev yapmakta olan 25 ortaokul matematik öğretmeniyle yürütülmüştür. Çalışma grubunu belirlemek için amaçlı örnekleme yöntemlerinden maksimum çeşitlilik örneklemesi kullanılmıştır. Amaçlı örnekleme yönteminde, kişiler ve mekanlar çalışmaya uygun olarak seçilmektedir. Çünkü bu kişiler çalışma probleminin ve çalışmanın merkezinde olan fenomenin anlaşılmasına yönelik istekli bilgi verebileceklerdir (Creswell, 2013). Öğretmenlerin 2020 yılının bahar ve güz döneminde uzaktan eğitimde matematik öğretim deneyimine sahip olmaları ön koşul kriteri olarak alınmıştır. Bununla birlikte öğretmenlerin devlet ve özel okullarda görev yapması; devlet okullarının ise kırsal, kent merkezi ve varoşlardaki okullardan seçilmesi ölçüt olarak alınarak maksimum çeşitlilik sağlanmaya çalışıımıştır. Ayrıca öğretmenlerin çalışmaya istekli olarak katılımları önemsenmiştir. Katılımcı öğretmenlerin betimleyici özellikleri Tablo 1'de özetlenmiştir. 
Tablo 1.

Katılımcı öğretmenlerin betimleyici özelliklerine ilişkin bilgiler

\begin{tabular}{llc}
\hline & & Frekans \\
\hline \multirow{2}{*}{ Cinsiyet } & Kadın & 18 \\
& Erkek & 7 \\
Hizmet süresi & $1-5 \mathrm{yıl}$ & 8 \\
& $6-10 \mathrm{yıl}$ & 9 \\
& $11-15 \mathrm{yıl}$ & 6 \\
\multirow{2}{*}{ Okulların bulunduğu bölge } & $16-20 \mathrm{yıl}$ & 2 \\
& Kırsal & 4 \\
Okul türleri & Kent merkezi & 17 \\
& Varoşlar & 4 \\
& Devlet okulu & 22 \\
\hline
\end{tabular}

\section{Veri Toplama Araçları}

Fenomenolojik bir çalışmada veri toplamanın en yaygın yolu, katılımcıların deneyimleriyle ilgili kapsamlı bilgi elde etmek amacıyla görüşme tekniğinin kullanılmasıdır. Mevcut çalışmanın verileri de katılımcı öğretmenlerle yapılan online görüşmelerden elde edilmiştir. Ortaokul matematik öğretmenlerinin uzaktan eğitimde matematik öğretim deneyimlerini ortaya koymak amacıyla araştırmacılar tarafından yarı yapılandırılmış bir görüşme formu hazırlanmıştır. Bu formun ilk hali beş açık uçlu sorudan oluşmaktadır. İlk soru, katılımcı öğretmenlerin 2019-2020 eğitim öğretim yılının bahar dönemi uzaktan eğitimde matematik öğretimine ilişkin yaşadıklarını sorunların neler olduğunu belirlemek amacıyla hazırlanmıştır. ìkinci soru, öğretmenlerin karşılaştıkları sorunların üstesinden gelebilmek için 2020-2021 eğitim öğretim yılının güz döneminde ne tür tedbirler aldıklarını ortaya koymayı amaçlamaktadır. Üçüncü, dördüncü ve beşinci sorular, öğretmenlerin her iki dönemde kullandıkları uzaktan öğretim programlarını, materyallerini ve yöntemlerini karşılaştırarak herhangi bir değişiklik olup olmadığını ortaya koymak amacıyla hazırlanmıştır.

Görüşme soruları hazırlandıktan sonra araştırmanın amacına uygunluğunu, anlaşılırlığını ve kullanılabilirliğini kontrol etmek amacıyla bir matematik eğitimcisinin görüşleri alınmış ve sorular üzerinde bazı düzenlemeler yapılmıştır. Örneğin sorularda yer alan "geçen dönem" ifadesi yerine "2019- 2020 eğitim-öğretim yılı bahar dönemi" yine "bu dönem" yerine "2020-2021 eğitim-öğretim yılın güz dönemi" ifadeleri kullanılmıştır. Daha sonra pilot uygulama için araştırmaya dahil olmayan iki matematik öğretmeniyle görüşme yapılarak soruların anlaşılır olup olmadığı ve öğretmenlerin yanıtlarının soruların içeriğini karşılayıp karşılamadığı belirlenmeye çalışılıı̧tır. Pilot uygulama sonucunda öğretmenlerin görüşme formunda yer alan üçüncü ve dördüncü sorulara aynı cevapları tekrar verdikleri görülmüş ve bu iki soru birleştirilerek bir soru oluşturulmuştur. Böylece görüşme formunun son hali dört açık uçlu sorudan oluşmaktadır.

\section{Veri Toplama Süreci}

Araştırmanın verilerinin toplanabilmesi amacıyla öncelikle Atatürk Üniversitesi Eğitim Bilimleri Birim Etik Kurul Başkanlığı'ndan 01/12/2020 tarih ve 56785782-050.02.04-E.2000300099 sayı numarası ile etik kurul uygunluk onayı alınmıştır. Etik kurulu onayı alındıktan sonra Aralık ayında öğretmenlerle yarı yapılandırımış online görüşmeler yapılmıştır. Öğretmenlere katılımcı onam formu gönderilerek 
çalışmanın amacından bahsedilmiş, çalışma sürecinin devam eden Covid-19 salgını nedeniyle online görüşmelerle yürütüleceği, isimlerinin gizli tutulacağı ve görüşmelerin sadece bilimsel amaçlarla kullanılacağı belirtilmiştir. Çalışmaya istekli katılan öğretmenler ile Zoom üzerinden yaklaşık 15-20 dakika süren görüşmeler yapılmış ve bu görüşmeler kayıt altına alınmıştır. Ayrıca görüşmeler sırasında öğretmenlerin sorulara verdikleri yanıtlar özetlenmiş ve doğruluğuna ilişkin teyit etmeleri istenmiştir. Katılımcı öğretmenlerin isimleri Ö1, Ö2, Ö3, ..., Ö25 şeklinde kodlanmıştır.

\section{Verilerin Analizi}

Araştırmada elde edilen verilerin incelenmesinde içerik analizi tekniği kullanılmıştır. İçerik analizi, araştırma verilerinden içeriğine ilişkin yinelenebilir ve geçerli sonuçlar ortaya çıkarmak amacıyla kullanılan bir araştırma tekniğidir (Krippendorff, 2018, s. 24). İçerik analizinin temel amacı ise elde edilen verilerin kavramsallaştırılması ve ilişkilendirilmesidir (Yıldırım \& Şimşek, 2016, s. 242). Bu amaç doğrultusunda kodlama sürecinde öncelikli olarak görüşme formunda yer alan soruların içeriğine uygun temalar belirlenmiştir. Daha sonra her bir soru için katılımcı öğretmenlerin yanıtları detaylı bir şekilde değerlendirilerek öğretmenlerin görüşlerini yansıtabilecek kodlar oluşturulmuştur. Ortaya çıkan kodlar benzerlik ve farklılıklarına göre kategoriler altında toplanarak kodlama işlemi tamamlanmıştır. Çalışma verilerinin kodlaması araştırmacılar tarafından ayrı ayrı yapıımış ve fikir uyuşmazlığının olduğu durumlar belirlenerek tekrar ele alınmıştır. Örneğin, araştırmacılardan biri öğretmenlerin karşılaştıkları zorluklar arasında yer alan "ders süresinin yeterli olmaması" kodunu "okul yönetimi kaynaklı" kategorisi altında yer verirken diğer araştırmacı "matematik dersine özgü" kategorisi altında değerlendirmiştir. i̇ki araştırmacı Zoom üzerinden yaptıkları tartışmada ders süresinin matematik dersleri için yeterli olmadığı konusunda hemfikir olmuşlardır.

Kodlama işleminin güvenirliğini artırmak amacıyla, elde edilen çalışma verileri iki araştırmacı tarafından ayrı ayrı incelenmiştir. Araştırmacılar arasındaki uyum Miles ve Huberman'ın (1994) uyuşum yüzdesi formülü kullanılarak hesaplanmıştır. Mevcut çalışma kapsamında iki kodlayıcı arasındaki uzlaşma \%91 olarak bulunmuştur. Hesaplanan bu değer kodlama işleminin istenilen düzeyde bir güvenirlik sağladığını göstermektedir. Ayrıca çalışmada katıımcı öğretmenlerin doğrudan görüşlerine yer verilerek zengin ve yoğun betimlemeler yapılmıştır.

\section{Bulgular}

Yapılan araştırmada, ortaokul matematik öğretmenlerinin pandemi sürecinde uzaktan eğitimde matematik öğretim deneyimleri yansıtılmaya çalışımıştır. Bu amaçla öğretmenlerle derinlemesine online görüşmeler gerçekleştirilmiştir. Yapılan görüşmelerde öğretmenlere dört soru yöneltilmiştir. Öğretmenlerin her soru için verdikleri yanıtlar analiz edilmiş ve oluşturulan kodlar ve kategoriler tablolar halinde düzenlenerek sunulmuştur.

\section{Uzaktan eğitim sürecinde yaşanılan zorluklar}

Ortaokul matematik öğretmenlerinin uzaktan eğitim sürecinde yaşadıkları zorlukları belirleyebilmek için "2019-2020 eğitim öğretim yılı bahar döneminde canlı derslerinizi yürütürken hangi zorluklarla karşılaştınız?" sorusu yöneltilmiştir. Öğretmenlerin yanıtları doğrultusunda oluşturulan kodlamalar Tablo 2' de verilmiştir.

Tablo 2.

Öğretmenlerin uzaktan eğitim sürecinde yaşadıkları zorluklar 


\begin{tabular}{|c|c|c|c|}
\hline Temalar & Kategoriler & Kodlar & $f$ \\
\hline \multirow{29}{*}{$\begin{array}{l}\text { Öğretim elemanları } \\
\text { kaynaklı zorluklar }\end{array}$} & \multirow{12}{*}{$\begin{array}{l}\text { Öğrenci } \\
\text { kaynaklı }\end{array}$} & Dönüt vermeme & 6 \\
\hline & & Ekranı kullanma zorluğu & 4 \\
\hline & & Mikrofon ve kamerayı etkinleştirmeme & 4 \\
\hline & & Konuları tekrar etmeme & 2 \\
\hline & & Aynı anda konuşma & 2 \\
\hline & & Öğretmeni tanımama & 2 \\
\hline & & Ekrana bakma yorgunluğu & 1 \\
\hline & & Sisteme ulaşamama & 1 \\
\hline & & Ekranı gereksiz yere kullanma & 3 \\
\hline & & Katılım yetersizliği & 12 \\
\hline & & Öğrenme zorluğu & 2 \\
\hline & & Derse karşı ilgisizlik & 7 \\
\hline & \multirow{11}{*}{$\begin{array}{l}\text { Öğretici } \\
\text { kaynaklı }\end{array}$} & Belirsizlik yaşama & 2 \\
\hline & & Hazırlıksız olma & 4 \\
\hline & & Canlı yayın heyecanı & 1 \\
\hline & & Deneyimsiz olma & 6 \\
\hline & & Öğrencinin ilgisini çekememe & 2 \\
\hline & & Konuları yetiştirememe & 5 \\
\hline & & Programı kullanmakta zorlanma & 9 \\
\hline & & Materyal-doküman eksikliği & 6 \\
\hline & & Ekranı kullanmada zorlanma & 5 \\
\hline & & İçerik hazırlama zorluğu & 2 \\
\hline & & Etkinlik uygulama zorluğu & 3 \\
\hline & \multirow{6}{*}{$\begin{array}{l}\text { Matematiksel } \\
\text { içeriğe özgü }\end{array}$} & Matematik öğretimini bilgisayar üzerinden yapma zorluğu & 5 \\
\hline & & Soyut yapısının olması & 5 \\
\hline & & Matematiksel gösterimleri kullanma & 15 \\
\hline & & Matematiksel işlemler yapma & 3 \\
\hline & & Konuların bağlantılı olması & 3 \\
\hline & & Ders süresinin yeterli olmaması & 9 \\
\hline \multirow{13}{*}{$\begin{array}{c}\text { Teknoloji kaynaklı } \\
\text { zorluklar }\end{array}$} & \multirow{10}{*}{$\begin{array}{l}\text { Canlı ders } \\
\text { uygulamaları } \\
\text { kaynaklı }\end{array}$} & Öğrencinin anlayıp anlamadığını tespit edememe & 4 \\
\hline & & Öğrenci mikrofonunun olmaması & 6 \\
\hline & & Birebir soru çözememe & 7 \\
\hline & & Yorum kısmının kapalı olması & 1 \\
\hline & & Öğrenciyi kontrol edememe & 8 \\
\hline & & Kullanılan programın alt yapısının yeterli olmaması & 10 \\
\hline & & Öğrenciyi görememe & 8 \\
\hline & & Senkron sıkıntısı & 1 \\
\hline & & Öğrencilerle doküman paylaşamama & 4 \\
\hline & & Programın güvenirliği & 4 \\
\hline & \multirow{3}{*}{$\begin{array}{l}\text { Internet } \\
\text { kaynaklı }\end{array}$} & Bağlanamama & 14 \\
\hline & & Yavaş olması & 3 \\
\hline & & Sistemden sürekli düşme & 5 \\
\hline \multirow{7}{*}{$\begin{array}{l}\text { Dış faktör kaynaklı } \\
\text { zorluklar }\end{array}$} & \multirow{2}{*}{$\begin{array}{c}\text { Okul yönetimi } \\
\text { kaynaklı }\end{array}$} & Ders saatlerinin uygun ayarlanmaması & 3 \\
\hline & & Öğretmen fikrinin alınmaması & 3 \\
\hline & \multirow{5}{*}{ Veli kaynaklı } & Ders ortamının uygun olmaması & 2 \\
\hline & & Bilişsel iletişim araçlarının yetersizliği & 5 \\
\hline & & İnternet erişiminin olmaması & 17 \\
\hline & & Destek vermemesi & 1 \\
\hline & & İletişim kurulamaması & 3 \\
\hline
\end{tabular}


Tablo 2 incelendiğinde, öğretmenlerin canlı derslerde karşılaştıkları zorluklar "Öğretim elemanları kaynakı", "Teknoloji kaynakı" ve "Dış faktör kaynakı" olmak üzere üç tema altında sınıflandırılmıştır. Öğretim elemanları kaynaklı zorluklar; öğrenci kaynaklı, öğretici kaynaklı ve içeriğe özgü zorluklar olmak üzere üç kategoriden oluşmaktadır. Öğretmenler, canlı derslerde yaşadıkları zorlukları dile getirirken öğrenci ve öğretici kaynaklı zorluklar hakkında oldukça detaylı açıklamalar yapmışlardır. Bu yönde öğretmenlerin ifade ettikleri öğrenci kaynaklı zorluklar arasında "katılım yetersizliği" olarak elde edilen kod, az sayıda öğrencinin canlı derse katılmasıdır ve görüşmeler sırasında öğretmenlerin en fazla üzerinde durdukları sorunlardan biridir. Bu durum ile ilgili olarak Ö8 "Öğrencilerin genel olarak derslere katılımı azdı. Aslında anlatılan derslerin notlara yansımaması ve yaz tatilinde bu derslerin telafisinin olacağını düşünmelerinden dolayı derslere katılmadılar..." şeklinde görüşlerini ifade etmiş ve katılım yetersizliğinin sebebi olarak herhangi bir ölçme ve değerlendirmenin yapılmamasını göstermiştir. Bazı öğretmenler ise canlı derslere katılan öğrencilerin derse karşı ilgisizliğinden ve yeterince dönüt alamadıklarından bahsetmişlerdir. Örneğin, Ö3 bu duruma ilişkin görüşlerini "...Katılımı olan öğrencilerle de yüz yüze iletişim kuramadığım için öğrencinin ne yaptığını bilemiyordum. Bazen arkadan bilgisayar oyunu sesleri geliyordu, kontrol etmek için soru sorduğumda ya hiç cevap alamıyordum ya da soruları tekrarlamak zorunda kalıyordum." şeklinde ifade etmiştir. Öte yandan öğretmenler, canlı derslerde öğrencilerin mikrofon ve kameralarını etkin hale getirmediklerini ya da etkileştirdiklerinde aynı anda konuşmaya başladıklarını belirtmişlerdir. Iki öğretmen ise öğrencilerin konuları tekrar etmediklerinden dolayı aynı konuları defalarca anlatmak zorunda kaldıklarından bahsetmişlerdir. Bu yönde farklı bir noktaya dikkat çeken Ö13, öğrencilerin sürekli ekran başında olmalarından dolayı ekrana bakma yorgunluğu yaşadıklarını tespit etmiştir.

Yapılan görüşmelerde öğretmenler, öğrenci kaynaklı zorlukların yanı sıra kendilerinden kaynaklanan sorunları da dile getirmişlerdir. Öğretmenlerin kendilerinden kaynaklı zorlukları detaylı bir şekilde açıklamaları ve sürece eleştirel bir gözle bakmaları dikkate değer bir bulgudur. Pandeminin aniden gelmesiyle hazırlıksız yakalanan öğretmenlerin uzaktan eğitim süreci ve canlı dersler hakkında yeterince tecrübelerinin olmamasından dolayı çeşitli sorunlarla karşılaştıkları görülmektedir. Bu kapsamda "belirsizlik yaşama", "hazırlıksız olma" ve "deneyimsiz olma" gibi kodlar örnek olarak gösterilebilir (bkz. Tablo 2). Bununla ilgili olarak merkezi bir okulda görev yapan Ö10, uzaktan eğitimde derslerin nasıl yürütüleceğine ilişkin yaşadığı belirsizlik durumunu şöyle açıklamıştır: "Pandemi süreci ilk başladığında biz Zoom üzerinden canlı derslere başladık. Bu süreçte EBA canlı dersler henüz başlamamıştı. Acaba nasıl geçecek, uzaktan eğitimde dersler nasıl işlenecek belirsizliğini yaşadım." Ö10 yaşadığı bu belirsizlik durumu nedeniyle il bilişim teknoloji rehberliği koordinatörlüğünde gönüllü olarak uzaktan eğitim seminerlerine katıldığını belirtmiştir. Ö24 ise pandemi olması nedeniyle bütün eğitim camiasının yeni bir döneme girdiğinden söz etmiş ve devamında "...uzaktan eğitim dediğimiz bir eğitimi vermeye başladık... Bu süreçte çok hazırıksız olduğumuzdan canlı dersler de zorluklar yaşadık, alışma süreci sıkıntıı oldu." ifadeleriyle yaşadığı zorluklardan bahsetmiştir.

Öğretici kaynaklı zorluklar arasında öğretmenlerin en fazla yaşadıkları sorun ise canlı dersleri yürütmek için gereken uygulamaları kullanmaları olmuştur. Öğretmenlerin çoğu, uzaktan eğitime başladıklarında canlı dersleri yürütmek için kullandıkları programların işlevini, sınırlılıklarını ve avantajlarını öğrenmede zorlandıklarını ifade etmişlerdir. Bu bağlamda Ö16, uzaktan eğitime ilk başladığında kullandığı EBA canlı ders uygulamasının özelliklerini kullanmayı bilmediğinden bahsetmiştir. Canlı dersler başladığında varoş bir okulda görev yapmasından dolayı öğrencilerin maddi yetersizliklerinin olduğunu dile getirmiştir. Bu nedenle öğrencilerin derslere katılamadığını ifade ederek programın etkili ve zayıf yönlerini deneme yanılma yöntemini kullanarak keşfettiğini belirtmiştir. Merkezi bir okulda görev yapan Ö2 ise "...ilk defa canlı ders yaptığım için programın işlevini önce öğrenemedim. Canlı derslere Zoom üzerinden başladık. Fakat Zoom'un nasıl bir program olduğu hakkında alt yapım yoktu. Bu nedenle dersleri nasıl işleyeceğim hakkında bir bilgim de pek yoktu." ifadeleriyle programı işlevsel olarak kullanmakta yaşadığı sorunlardan bahsetmiştir. Bu kategori altında dikkat çeken diğer bir kod ise "Materyal-doküman eksikliği" olmuştur. Öğretmenler, ilk defa böyle bir 
durum ile karşılaştıklarını, canlı derslere uyumlu olarak kullanabilecekleri materyalleri ve dokümanları bulmalarının zor olduğunu ifade etmişlerdir. Bununla ilgili olarak Ö7 görüşlerini "...elimde yeterince kaynak kitabım olmadığı için ilk başlarda konu özetlerini A4 kâğıtlarına yazıyordum. Bunları Whatsapp aracılığıyla öğrencilerime ulaştırmaya çalışıyordum." şeklinde ifade etmiştir. Benzer şekilde varoş bir okulda görev yapan Ö16 ise her konu için sürekli dokümanlar araştırmanın ve uygun olan dokümanı bulmanın zor olduğunu belirtmiştir. Bunun yanı sıra öğretmenler, uzaktan eğitim sürecinde etkinlikleri uygulamada ve içerik hazırlamada sıkıntı yaşadıklarını, konuları yetiştiremediklerini ve canlı derslerde öğrencilerin ilgilerini yeterince çekemediklerini dile getirmişlerdir. Örneğin kırsal bir okulda görev yapan Ö13, "Öğrenciyle etkileşimim azaldığından gereken müdahaleyi zamanında yapamıyordum. Bu yüzden de eksiklik katlanarak devam ediyordu. Öğrencilerin birbiriyle etkileşimi de minimuma indiğinden canlı dersler öğrenci için de keyifli bir süreç olmaktan çıkıyordu..." ifadeleriyle canlı derslerde öğrenci-öğrenci etkileşimin yeterli olmamasına değinmiştir.

Yapılan görüşmelerde, öğretmenlerin matematik dersine özgü sorunlardan da bahsettikleri gözlenmiştir. Bahsi geçen sorunlar; matematik öğretimini bilgisayar üzerinden yapma, matematiğin soyut bir yapısının olması, matematiksel gösterimleri kullanma ve işlemler yapma, matematikte konuların birbiri ile bağlantılı olması ve canlı ders süresinin matematik dersleri için yeterli olmamasıdır. Öğretmenlerin çoğu, canlı dersleri yürütürken matematiksel gösterimleri kullanmada ve işlemleri yapmada zorlandıklarını ifade etmişlerdir. Bu duruma yönelik Ö9 "ilk başlarda canlı derslerimi EBA üzerinden yürüttüm benim teknolojiden uzak kalmam nedeniyle olabilir programı kullanırken matematiksel ifadeleri kullanmakta, ekrana yazmakta, işlemleri tahtaya yapmakta zorluk çektim." açıklamalarını yapmış ve görüşmenin devamında "... zaten ders soyuttu uzaktan anlatınca ve iletişim de azalınca daha da soyutlaştı. Materyalleri elimize alıp inceleme imkânımız bile olmadı. Bu durumda konular ve matematiksel kavramlar öğrenciler için daha da zorlaştı." şeklinde görüşlerini ifade etmiştir. Matematik dersinde yer alan konuların birbiriyle bağlantılı olduğunu belirten üç öğretmen ise öğrencilerin canlı derslerden birine katılmamaları durumunda diğer konuları anlamalarının ve ilişkilendirmelerinin çok zor olduğunu belirtmiştir.

Öğretmenlerin uzaktan matematik öğretimi sürecinde özellikle teknoloji kaynaklı birçok sorunla karşılaştıkları görülmüştür. Bu sorunlar; canlı ders uygulamaları kaynaklı ve internet kaynaklı olmak üzere iki kategoride ele alınmıştır. Öğretmenler, canlı derslerini yürütmek için kullandıkları programların alt yapısının yeterli olmamasından dolayı bazı sorunlarla karşılaşmışlardır. Bu durumu destekleyici açıklamalarda bulunan Ö15 "Canlı derslere girmekte zorluk yaşadım. EBA'nın altyapısı yeterli değildi. Bazı zamanlar derse girebilmek için tekrar tekrar denemeler yaptım..." şeklinde görüşlerini ifade etmiştir. Uzaktan eğitimde öğretmenler bazı öğrencilerin mikrofonunun ve kamerasının aktif olmaması nedeniyle yeterince etkileşim kuramadıklarını belirtmişlerdir. Bu durumun öğretmenlerin canlı dersler esnasında öğrencileri kontrol edememesine ve dolayısıyla öğrencilerin dersi anlayıp anlamadığını tespit edememesine yol açtığı görülmüştür. Öğrencilerle yeterince etkileşim sağlayamadığını belirten Ö22, açıklamalarını şöyle dile getirmiştir: "EBA ve Zoom üzerinden işlediğimiz derslerde öğrencilerin kameralarını açmalarına izin verilmediği için öğrenci ile iletişime geçmek, göz göze temas kurmak, öğrenciyi takip etmek gibi konularda sıkıntı yaşadım." Benzer şekilde öğrencinin gözünün içine bakarak ders anlatmamanın ve onlarla yeterince etkileşim sağlayamamanın zorluğundan bahseden Ö17, yaşadığı bu zorluğun başka zorlukları da beraberinde getirdiğini belirtmiştir. Örneğin, hangi öğrencinin anlayıp hangi öğrencinin anlamadığını tespit edemediğini, anlatımlarında sadece öğrencinin anladığını kabul ettiğini, öğrencilerin dersle ilgili notlar alıp almadıklarını göremediğini ifade etmiştir. Benzer şekilde Ö6 "...(öğrencilerin) yüzlerini görmediğim zaman duvara anlatıyor gibi oluyordum." ifadeleriyle duygularını ön plana çıkararak öğrenci-öğretici etkileşiminin yeterli olmamasından bahsetmiştir. Bazı öğretmenler ise kullanılan programın güvenirliği konusunda sıkıntılar yaşadıklarını dile getirmişlerdir. Bununla ilgili olarak Ö8, "Bazı öğrencilerimiz sisteme ulaşamadığı gibi bazı öğrencilerimiz de yayılan söylentilerden dolayı Zoom programının güvenirliği açısından tedirginlik yaşadılar ve canlı derslere girmeye çekindiler." ifadelerine yer vermiştir. 
Canlı ders uygulamaları kaynaklı sorunlardan bir diğeri ise öğrencilerle birebir soru ve problem çözememektir. Bu durumu anlatırken özel okulda görev yapan Ö11 "...soru sorunca çocuklardan geri dönüt alamıyordum... birebir soru çözemiyordum." ifadelerini kullanmıştır. Ö11'e göre öğrencilerle birebir soru çözememek canlı derslerin verimli olmamasına neden olmaktadır. Özel okulda görev yapan Ö5 ise uzaktan eğitim başladığında diğer öğretmenlerden farklı olarak Youtube üzerinden canlı derslerini yürütmüştür. Ancak Youtube üzerinden canlı dersleri yürütmesinin farklı sorunlarla karşılaşmasına sebep olduğunu dile getirmiş ve devamında "...okul olarak ilk etapta Youtube üzerinden canlı dersleri verdik. Youtube üzerinden yaptığımız bu derslerde öğrencilerimiz sorduğumuz sorulara cevap veremediği gibi anlayıp anlamadıklarına dair bize herhangi bir bilgi de veremedi...Yani canlı ders esnasında öğrenci direk derse katılamadığı için yeterince iletişime geçilemedi..." ifadelerini kullanarak senkron sıkıntısı yaşadığını belirtmiştir. Ayrıca Ö5, kullandıkları programda yorum kısmının kapalı olmasının öğrenci geri dönütlerini almalarında bir engel teşkil ettiğini vurgulamıştır. Yapılan görüşmelerde öğretmenlerin internet kaynaklı sorunlardan da oldukça fazla bahsettikleri tespit edilmiştir. Bu sorunlar içerisinde en sık görülen ise öğrencilerin ya da öğretmenlerin internete bağlanamamasıdır. Nitekim Ö19 bu durumu "Derslerim de karşılaştığım en büyük sıkıntı öğrencilerimin derse bağlanmakta sorun yaşamasıdır. Çoğu öğrencim canlı derslere hiç bağlanamadılar." ifadeleri ile vurgulamıştır. Öğretmenler ayrıca internet bağlantısı olsa bile sürekli sistemden düşme sıkıntısı yaşadıklarını ve internetin yavaş olmasından dolayı derslere zamanında katılmanın aksadığını belirtmişlerdir.

Görüşmelere katılan öğretmenler, okul yönetimi ve veli kaynaklı zorluklardan da bahsetmişlerdir. Bu zorluklar "Dış faktör kaynaklı zorluklar" teması altında incelenmiştir. Bu yönde öğretmenler, ders saatlerinin uygun ayarlanmadığından ve uzaktan eğitim sürecinde kendi fikirlerinin yeterince dikkate alınmadığından bahsederek okul yönetiminden kaynaklanan bazı zorlukları dile getirmişlerdir. Konuyla ilgili düşüncelerini dile getiren Ö7, okul yönetiminin hazırladığı canlı ders programında matematik derslerinin akşam saatlerinde yapılmasını uygun bulmadığını ancak bu yönde fikrinin alınmadığını belirtmiştir. Tüm bu zorlukların yanı sıra özellikle kırsal ve varoş okullarda görev yapan öğretmenlerin, maddi sıkıntılardan dolayı velilerin telefonlarında internet paketlerinin olmamasını ya da evlerinde sabit bir internet hattının olmamasını sıklıkla dile getirdikleri görülmüştür. Örneğin, varoş bir okulda görev yapan Ö16, öğrencilerinin maddi yetersizlikler nedeniyle internete erişemediğini dile getirmiştir. Benzer şekilde bir köy okulunda görev yapan Ö18 ise "...öğrencilerimin internet sorunu vardı. Köyde internet çekmediğinden dolayı öğrenciler derse katılamadılar." ifadeleriyle yaşadığı sorunu dile getirmiştir. İnternet sıkıntısının öğretmenlerin canlı dersleri yürütürken en fazla karşılaştıkları sorun olduğu görülmüştür. Ö6 bu durumu "internet sorunu bizim en büyük problemimizdi." şeklinde vurgulamıştır. Bu kategoride diğer bir dikkat çeken durum ise "bilişsel iletişim araçlarının yetersizliği" olarak kodlanan; velilerin telefon, tablet ve bilgisayar gibi bilişsel iletişim araçlarını temin edememesinden kaynaklanan sıkıntılar olmuştur. Yaşadığı en büyük sıkıntıyı eğitimde fırsat eşitsizliğinin olması şeklinde ifade eden Ö16 "Bazı öğrenciler velilerinin telefonundan derslere girdiği için sadece akşam, babaları evde olduğunda canlı derslere katılabiliyorlardı. Bazı öğrenciler ise evde akıllı telefon, tablet ya da bilgisayar gibi canlı derslere girebileceği herhangi bir araç olmadığından dolayı hiçbir dersime katılamıyordu." ifadeleriyle karşılaşığı sorunları açıklamıştır. Yapılan görüşmelerde iki öğretmen ise öğrencilerin ders ortamının uygun olmamasından kaynaklanan sıkıntılara dikkat çekmiştir. Bu durumu Ö7 “...uzaktan eğitimde her bir öğrencinin kendi aile ortamında derslere katıldığını düşünürsek, ders esnasında bile neler yaşadıklarını, dikkatlerini derse ne kadar verebildiklerini bilemiyorduk." şeklinde ifade etmiştir.

\section{Uzaktan eğitim sürecinde yaşanılan zorluklara ilişkin alınan tedbirler}

Görüşmelerde öğretmenlere ikinci soru olarak "Uzaktan eğitim sürecinin bahar döneminde yaşadığınız zorluklar için 2020-2021 eğitim öğretim yılının güz döneminde ne tür tedbirler aldınız? Ne 
tür tedbirlerin alındığını düşünüyorsunuz?" soruları yöneltilmiştir. Öğretmenlerin verdikleri yanıtlara ilişkin oluşturulan kodlamalar Tablo 3’ de verilmiştir.

Tablo 3.

Uzaktan eğitim sürecinde yaşanılan zorluklara yönelik alınan tedbirler

\begin{tabular}{|c|c|c|c|}
\hline Tema & Kategoriler & Kodlar & $f$ \\
\hline & & Kullanılan program sayısını artırma & 9 \\
\hline & & İnternet alt yapısının uygunluğunu kontrol etme & 2 \\
\hline & Teknolojiyi takip etme ve & Kullanılan programın içeriğini öğrenme & 8 \\
\hline & kullanma & $\begin{array}{l}\text { İnternetten diğer öğretmenlerin derslerini nasıl } \\
\text { yürüttüğünü araştırma }\end{array}$ & 3 \\
\hline & & Grafik/Kalemli tablet kullanma & 9 \\
\hline & Doküman/Materyal eksikliğini & Eğitici animasyonlar ve videolar kullanma & 4 \\
\hline & giderme & Çalışma yaprakları hazırlama & 4 \\
\hline & & Kaynak kitap temin etme & 7 \\
\hline & & Konu özetleri hazırlama & 4 \\
\hline & & Bilişsel eğitim materyalleri alma & 4 \\
\hline & Öğrencinin aktif katılımını & Öğrencileri ödevlendirme & 12 \\
\hline & sağlama & Öğrencilerin ön hazırlık yapmalarını sağlama & 7 \\
\hline & & $\begin{array}{l}\text { Öğrenciye planlı ders çalışma alışkanlığı } \\
\text { kazandırma }\end{array}$ & 2 \\
\hline & & Öğrenci ödevlerini takip etme & 8 \\
\hline & & Öğrencinin derse katılıp katılmadığını takip etme & 15 \\
\hline & & $\begin{array}{l}\text { Öğrencilerin işlemlerini ve cevaplarını sözel } \\
\text { olarak açıklaması isteme }\end{array}$ & 4 \\
\hline \multirow[t]{21}{*}{ Öğretici tedbirleri } & & $\begin{array}{l}\text { Problemleri öğrencilerin defterlerine } \\
\text { kendilerinin çözmelerini isteme }\end{array}$ & 3 \\
\hline & & Öğrencilerin ders notu tutmalarını isteme & 2 \\
\hline & & Ödül ve pekiştireç kullanma & 6 \\
\hline & Ders süresini etkin kullanma & Ders öncesi hazırlık yapma (planlama) & 5 \\
\hline & & Z kitaplar kullanma & 10 \\
\hline & & Canlı ders kurallarını belirleme & 7 \\
\hline & & Sınıf ortamı oluşturma & 2 \\
\hline & & Somut materyal kullanma & 3 \\
\hline & & Soru cevap yöntemini daha sık kullanma & 11 \\
\hline & & Tahta kullanma & 8 \\
\hline & & Farklı öğretim yöntemleri kullanma & 2 \\
\hline & & Öğrenci grupları oluşturma & 1 \\
\hline & & Soru çözme & 2 \\
\hline & İletişim yollarını artırma & Öğrencilerle görüşme yapma & 1 \\
\hline & & Whatsapp grupları oluşturma & 8 \\
\hline & & Veli ile iletişim kurma & 2 \\
\hline & & Meslektaşları ile iletişim kurma & 3 \\
\hline & & Öğrenci sorularını çözüp fotoğrafını gönderme & 4 \\
\hline & & $\begin{array}{l}\text { Canlı derse giremeyen öğrencilere ders notlarını } \\
\text { elden ulaştırma }\end{array}$ & 1 \\
\hline & Teknoloji desteği & Sabit internet hattı bağlatma & 7 \\
\hline & & Akıllı telefon alma & 4 \\
\hline \multirow[t]{3}{*}{ Veli tedbirleri } & & İnternet paketlerini genişletme & 2 \\
\hline & & Öğrencilere tablet ve bilgisayar alma & 3 \\
\hline & İletişim desteği & Okul ile iş birliği yapma & 2 \\
\hline
\end{tabular}




\begin{tabular}{|c|c|c|c|}
\hline & & Öğretmen ile iletişime geçme & 3 \\
\hline & Öğrenciye desteği & Öğrenciyi takip etme & 2 \\
\hline & & Uygun ortam hazırlama & 6 \\
\hline & & Programı kullanmayı öğrenme & 5 \\
\hline & Teknolojiden faydalanma & EBA destek noktasını kullanma & 6 \\
\hline \multirow{5}{*}{ Öğrenci tedbirleri } & & Ortak internet kullanma & 1 \\
\hline & & Ders öncesi hazırlık yapma & 2 \\
\hline & Aktif katılım sağlama & Derse katılım sağlama & 2 \\
\hline & & Ders notları alma & 4 \\
\hline & & Verilen görevleri yerine getirme & 5 \\
\hline \multirow{6}{*}{$\begin{array}{l}\text { Okul yönetimi } \\
\text { tedbirleri }\end{array}$} & Ders programı hazırlama & Ders saatlerini düzenleme & 3 \\
\hline & & Ders sayısını artırma & 5 \\
\hline & Ortam hazırlama & $\begin{array}{l}\text { Öğretmenlere canlı ders için sınıf ortamı } \\
\text { hazırlama }\end{array}$ & 2 \\
\hline & & Öğrencilere EBA destek noktası oluşturma & 6 \\
\hline & İletişimi artırma & Veli ile iletişim kurma & 3 \\
\hline & & Öğretmenlerle iş birliği yapma & 5 \\
\hline
\end{tabular}

Tablo 3 incelendiğinde, uzaktan eğitim sürecinde yaşanılan zorluklara yönelik alınan tedbirler incelendiğinde "Öğretici tedbirleri", "Veli tedbirleri", "Öğrenci tedbirleri" ve "Okul yönetimi tedbirleri" olmak üzere dört tema altında sınıflandırılmıştır. Öğretici tedbirleri teknolojiyi takip etme ve kullanma, doküman/materyal eksikliğini giderme, öğrencinin aktif katılımını sağlama, ders süresini etkin kullanma, iletişim yollarını artırma olmak üzere beş kategoriden oluşmaktadır.

Öğretmenlerin canlı derslerde öğretici kaynaklı zorluklar hakkında yaptıkları ayrıntılı tespitler, yaşanan bu sıkıntılara yönelik alınan tedbirlerin de sayıca fazla ve içerik olarak detaylı olmasına yol açmıştır. Bu yönde öğretmenlerin dile getirdikleri öğretici tedbirleri içerisinde teknolojiyi takip etme ve kullanma kategorisi incelendiğinde "kullanılan program sayısını artırma", öğretmenlerin canlı derslerini yürütürken farklı programları denemeleri ve bunlardan birkaçını birlikte kullanmaya başlamalarıdır. Görüşmelerde öğretmenlerin kullanılan programlar üzerinde oldukça fazla çaba sarf ettikleri görülmektedir. Bununla ilgili olarak, Ö14 "Geçen dönem sadece EBA ve Whatsapp uygulamalarını kullandım. Bu dönem ise Zoom, EBA, Whatsapp ve Microsoft Team kullanıyorum. Ayrıca Quiziz, Padlet gibi web programlarını da öğrencinin ilgisini çekmek için derslerde kullanmaya başladım." şeklinde görüşlerini ifade etmiştir. Ö14'e göre öğrencinin ilgisini çekebilecek uygulamaların derslerde kullanılması öğrenciler arasında etkileşimin de artmasını sağlayacaktır.

Yapılan görüşmelerde, öğretmenler canlı ders uygulamalarının içeriklerini araştırarak özelliklerini kullanmayı öğrendiklerinden bahsetmişlerdir. Örneğin bu duruma ilişkin görüşlerini Ö9, "Öncelikle program üzerinde neler yapabileceğimi öğrendim. Programın kısıtlı yönlerini ve gelişmiş yönlerini inceledim..." şeklinde ifade etmiştir. Ö9 ise "Matematik öğretmenlerinin ne tür zorluklar yaşadığını ve bunlara ne tür çözümler bulunduğunu internetten araştırıp çözümleri kendim de denedim." ifadeleri ile internet ortamında diğer öğretmenlerin derslerini nasıl yürüttüğünü araştırdığını belirtmiştir. Bu kapsamda Ö20, "interneti takip ettim. Matematik derslerini sözel olarak anlatmak öğrenci için hiçbir anlam ifade etmediği için diğer matematik öğretmenlerinin nasıl ders işlediklerine (internetten) baktım." ifadelerini kullanmıştır. Bunun yanı sıra ekranı kullanma, matematik öğretimini bilgisayar üzerinden yapma, matematiksel gösterimleri kullanma ve işlemler yapma gibi zorlukların üstesinden gelebilmek için grafik ya da kalemli tablet aldıklarından bahsetmişlerdir.

Görüşmelere katılan öğretmenlerin materyal eksikliğini gidermek için eğitici animasyon ve videolar kullandıkları, çalısma yaprakları hazırladıkları, kaynak kitaplar temin ettikleri, konu özetleri hazırladıkları ve bilişsel eğitim materyalleri aldıkları belirlenmiştir. Örneğin, Ö21 “...farkı kaynaklar 
tarayarak farklı sorulara ulaşmaya çalışıyorum. Öğrenciler için çeşitli ders notları hazırladım... derslerimde bu notları kullanıyorum." şeklinde ifade etmiştir. Kırsal bir bölgede görev yapan Ö6 ise doküman eksikliğini gidermek için yaptıklarını şu şekilde açıklamıştır: "Anlatacağım konuyu renkli renkli ve büyük büyük yazıp onları pdf halinde EBA alt yapısından canlı olarak öğrencilere açıp anlatıyorum. Whatsapp grupları oluşturup öğrencilere soruları oradan da gönderiyorum. Ayrıca öğrenci soruları için haftanın belirli günlerini soru çözümüne ayırdık. Bu süreçte çalışma kâğıtları, denemeler, testler ne buluyorsak kaynak olarak kullanıyoruz." Öğretmenler, canlı derslerde öğrencilerin aktif katılımlarını sağlamak için çaba gösterdiklerini ifade etmişlerdir. Bu amaçla öğrencilerin canlı derslere katılıp katılmadıklarını takip ettiklerini, öğrencilerin işlemlerini ve cevaplarını sözel olarak açıklamalarını istediklerini, problemleri öğrencilerin defterlerine kendilerinin çözmelerini beklediklerini, öğrencilerin ders notları almalarını istediklerini ifade etmişlerdir. Bu yönde, öğrencileriyle sürekli iletişim halinde olduğundan bahseden Ö5 "...onların sadece birer izleyici değil aynı zamanda birer katılımcı olduklarını hissettirmek için derslerimde öğrenciyi aktif tutmaya çalışıyorum..." açıklamalarında bulunmuştur. Ö6 ise "Öğrencileri canlı derslerde aktif tutabilmek için isim isim soru soruyorum. Soruyu önce anlamalarını bekliyorum. Anladıklarında çözüm yapmaları için onlardan adım adım işlemleri söylemelerini istiyorum." şeklinde görüşlerini dile getirmiştir. Öğrencileri aktif tutmak için ödül ve pekiştireç kullandıklarını belirten altı öğretmen ise kendilerine özgü yöntemler geliştirdiklerinden söz etmişlerdir. Örneğin, merkezi bir okulda görev yapan Ö7 kullandığı bir yöntemden şöyle bahsetmiştir: "Ders esnasında öğrencilere kısa cevaplı sorular sorup doğru cevap veren öğrencilere artı verip kendime ait bir artı eksi sistemi geliştirdim... Böylece öğrenciler artı almak için birbirleri ile yarışmaya başladılar..."

Görüşmeye katılan öğretmenler, sadece öğrencilerin canlı derslerde aktif olmalarını sağlamakla yetinmeyip aynı zamanda öğrencilerin ders dışı çalışmalarını da takip ettiklerini belirtmişlerdir. Bu yönde öğretmenlerin görüşleri, öğrencileri ödevlendirdikleri ve bu ödevleri takip ettikleri, öğrencilerin derslere ön hazırlık yapmalarını sağladıkları ve öğrencilere planlı ders çalışma alışkanlığı kazandırmaya çalıştıkları yönündedir. Görüşmeye katılan on iki öğretmenin öğrencilerine ödev gönderdiği ancak bu öğretmenlerden sekizinin ödevleri takip ettiği, dört öğretmenin ise öğrenci ve velisi ile yeterince iletişim kuramadığından öğrenci ödevlerini takip edemediği belirlenmiştir. Bu konuda Ö2 "Geçen dönem ödev göndermiyordum ama bu dönem ödevler göndermeye başladım. Öğrencilerin ödevlerini kontrol etmek için çözdükleri soruların fotoğraflarını istiyorum." ifadelerine yer vermiştir. Ödev takibi yaptığını söyleyen Ö7 ise görüşlerini şöyle belirtmiştir: "Ödevleri artık EBA'dan gönderiyorum, çözüp çözmediklerine dair raporlar veriyor. Raporları takip edip çözmeyen öğrencilere mesaj gönderip iletişime geçiyorum..." Nitekim Ö20 ödevleri takip edemediğini belirterek gerekçe olarak öğrencilerin geri dönüt vermemesini göstermiştir.

Uzaktan eğitimde matematik derslerinin verimli olabilmesi için öğretmenler ders süresini etkin bir şekilde kullanmaya çalışmışlardır. Bu yönde sadece öğrenci faaliyetlerine yoğunlaşmamış kendi gayretlerini de özellikle dile getirmişlerdir. Örneğin, merkezi bir okulda görev yapan Ö21 ders öncesi yaptığı hazırlıkları anlatırken "Ders öncesinde çalışmalar yaparak ders notlarımı hazırladım. Ayrıca her dersten önce farklı kaynaklar tarayarak farklı sorulara ulaşmaya çalıştım, bu soruları hangi sırayla çözeceğimi planladım." ifadelerini kullanmıştır. Canlı derslerini daha çok z-kitap üzerinden yürütmeyi tercih eden öğretmenler ise ders içeriğini zenginleştirmek ve öğrencinin ilgisini çekmek amacıyla kullandıklarını belirtmişlerdir. Ayrıca görüşmeye katılan öğretmenler, ders sürelerini etkili kullanabilmek için canlı ders kuralları oluşturduklarını belirtmişlerdir. Özellikle bu durumu dile getiren öğretmenlerin merkezi okullarda görev yapması dikkat çekmektedir. Bu yönde Ö4 açıklamalarını şöyle belirtmiştir: "...Yaşları küçük olduğu için (5. sınıf) ekranı bırakıp gitmek, yemek içmek gibi düzeltmem gereken çok sorun yaşadım... zor oldu alışana kadar sonrasında öğrencileri tek tek uyardım ve öğrencileri tam olarak dersin içine çekmek için canlı ders kuralları koyarak belirli bir denge kurabildim." Öğretmenlerin çoğu, belirlenen sürede daha etkin bir şekilde ders işlemek için özellikle soru cevap yöntemini geçen döneme göre daha sık kullanmaya başladıklarını ifade etmişlerdir. Buna ek olarak, iki öğretmen ise bu yöntemin dışında farklı öğrenme yöntemlerini canlı derslere kullanıp 
kullanamayacaklarını denediklerini başarılı olan öğretim yöntemlerini kullanmaya devam ettiklerini belirtmişlerdir. Diğer öğretmenlerin faaliyetlerinden farklı olarak özel okulda görev yapan Ö11, derslerin daha etkili olabilmesi için öğrenci grupları oluşturduğundan bahsetmiş ve görüşlerini açıklarken "...uzaktan testler yapmaya çalıştım... grupların yapamadığı soruları o gruba ek canlı ders yaparak ben anlattım. Öğrenci sayısını azalttığım için birebir ilgilenmeye başladım..." ifadelerine yer vermiş̧ir. Ayrıca derse ilgisiz olan öğrencilerle telefon görüşmeleri yaparak birebir ilgilendiğinden söz etmiş ve öğrencilerle iletişimi artırmaya çalıştığını belirtmiştir. Benzer şekilde, iletişim yollarını artırmaya çalışan Ö19 ise "Veliler ile görüşme yaparak derslere katılım sayısını ve derse katılan öğrencilerin motivasyonunu artırmaya çalışıtım." şeklinde görüşlerini dile getirmiştir. Görüşmeye katılan sekiz öğretmen, öğrencilerle iletişimlerini her daim sağlayabilmek için Whatsapp grupları oluşturduklarını ifade etmişlerdir. Bu yolla öğrencilerle aralıksız ve aracısız bir şekilde iletişim kurduklarını belirtmişlerdir. Öğrencilerin yapamadıkları soruları çözerek fotoğraflarını Whatsapp üzerinden gönderdiklerini belirten dört öğretmen, öğrencilerin bu sayede daha iyi öğrendiklerini ileri sürmüştür. Bazı öğretmenler ise meslektaşları ile iletişime geçtiklerini, bu süreçte neler yaptıkları ile ilgili bilgi aldıklarını, derslerin daha verimli geçmesi için birbirleriyle fikir alışverişinde bulunduklarını söylemiştir. Bir yatılı bölge okulunda görev yapan Ö18 "Bu dönem bütün veli ve öğrenciler tek tek aranarak ulaşıldı. Benim okulum yatılı bölge okulu olduğu için köy muhtarları ile konuşup iletişime geçildi. Hatta derse giremeyen öğrenciler için not kâğıtları, çalışma kâğıtları bazen muhtarlar aracılığı ile bazen de velinin okula gelmesi şeklinde öğrencilere ulaştırıldı." şeklinde görüşlerini dile getirmiştir.

Uzaktan eğitim sürecinde öğreticilerin dile getirdikleri veli tedbirleri; teknoloji desteği, iletişim desteği ve öğrenci desteği olmak üzere üç kategoride incelenmiştir. Öğretmenler, teknoloji desteği kapsamında, velilerin evlerine sabit bir internet hattı bağlatmalarını, akıllı telefon, tablet, bilgisayar almalarını ve telefonlarında var olan mevcut internet paketlerini genişletmelerini dile getirmişlerdir. Öyle ki öğretmenler, velilerin bu tedbirlerinin yeterli olmadığını, eğitimde fırsat eşitsizliğinin devam ettiğini ve bu konuda kat edilmesi gereken çok yol olduğunu belirtmişlerdir. Bu konuyla ilgili olarak Ö15 "Canlı dersler başlamadan öğrencilerime ulaştım. Telefon, tablet, internet temin durumlarını öğrendim. Bazı velilerim evlerine internet ve bilgisayar aldılar. Imkânı olmayan öğrencilerimin de isimlerini müdürümle paylaşarak öğrencilere yardımda bulunmaya çalıştık." açıklamalarını yaparken Ö24 ise maddi sıkıntısı olan öğrencilerini çeşitli yardım kuruluşlarına yönlendirdiğini belirtmiştir. Bununla birlikte Ö24, velilerin okul ile iş birliği yaptıklarını, öğretmenlerle iletişime geçerek bu süreçte öğrencileri için neler yapabileceğini sorduklarını belirterek veli ile birlikte süreç yönetimi yaptıklarından bahsetmiştir. Öğretmenler, uzaktan eğitim sürecinde velilerin aldıkları tedbirlerden bahsederken öğrencilere uygun ortam hazırlama konusunda oldukça çaba gösterdiklerini vurgulamışlardır. Bu yönde iki öğretmen velilerin evde çocuklarını yakından takip etmelerinden duydukları memnuniyeti dile getirmeyi inmal etmemiştir.

Yapılan görüşmelerde öğretmenler, uzaktan eğitim sürecinde canlı derslerde yaşanan sıkıntıların üstesinden gelebilmek için öğrencilerin de birtakım tedbirler aldıklarından bahsetmişlerdir. Bu süreçte öğrencilerin de teknolojiden faydalandıklarını belirtmişlerdir. Örneğin beş öğretmen, öğrencilerin canlı derslerde kullandıkları programı hızlıca öğrendiğini ve böylece uzaktan eğitime kolayca uyum sağladıklarını ifade etmişlerdir. Öğretmenlerin geneli, internet sıkıntısını sürekli gündeme getirmiş ve bu sıkıntıyı aşmak için öğrencilerin de çaba gösterdiğini anlatmıştır. Bu konuda Ö10 "Internete bağlanamayan çocuklar oluşturulan EBA destek noktalarına giderek derslere katılmaya başladılar." ifadelerine yer verirken Ö13 ise "...bazıları da haklı olarak bunun (eve sabit internet ve bilgisayar almanın) maliyetli olduğunu, durumunun olmadığını dile getirdi. Internet sorunu olan ögrenciler okuldaki EBA destek noktalarına giderek canlı derslere katılmaya çalıştılar." ifadelerine yer vermiştir. Köy okulundan gelen çocuklardan oluşan bir yatılı bölge okulunda görev yapan Ö18 ise öğrencilerinin köylerinde internet çekmediği için muhtarının çabalarıyla bir internet odası yaptıklarını, öğrencilerin bu internetin ücretini birlikte ödediklerini ve bu sayede canlı derslere katıldıklarını ifade etmiştir. 
Uzaktan eğitim sürecinde okul yönetiminin de çeşitli tedbirler aldığından bahseden öğretmenler, okul idaresinin ders programlarını düzenleyerek ders sayılarını artırdığını böylece öğretmenlerin daha düzenli bir şekilde dersleri yürüttüklerini ve ders sayılarının artmasından dolayı konuları yetiştirmeye başladıklarını ifade etmişlerdir. Örneğin Ö7, "Önceden ders saatleri öğretmenler için pek uygun olmuyordu, canlı ders saatlerini ayarlamak zordu. Şimdi okul idaresi ders programı yaptı ve her bir öğretmenin canlı ders saatlerini ayarlayarak sınıfların da derslere düzenli bir şekilde derslere katılmasını sağladı" şeklinde açıklamalarını yapmıştır. Ayrıca öğretmenler, okul yönetiminin interneti olmayan öğrenciler için EBA destek noktası oluşturduğunu ve öğrencilerin canlı derslere katılabilecekleri güvenli bir ortam sağladıklarını ifade etmişlerdir. Varoş bir okulda görev yapan Ö16, okul idaresinin öğretmenler için de canlı derslere girebilecekleri bir sınıf ortamı hazırladığını böylece tahtayı kullanarak ders anlattıklarını belirtmiştir. Ayrıca bu konuyla ilgili özel okulda görev yapan Ö4 ise "derslerin verimli olması için bu dönem okula gidip akıllı tahtadan Zoom'a bağlanarak anlattık. Akıllı tahta üzerine kamerayı yerleştirdik, ekranda yansıttık, yakamıza mikrofon taktık, etkili oldu" açıklamalarını yapmıştır. Ö4'e göre bu uygulamanın etkili olmasının sebebi, öğrencinin öğretmenini okulda görmesi ve kendini sınıfında hissetmesidir. Okul idaresinin öğretmenlerle iş birliği yaparak velilerle iletişim kurduğundan bahseden Ö4 "Okul idaresi ile birlikte her hafta velileri düzenli bir şekilde aradık. Canlı derslerle ilgili bilgilendirme yaptık. ... takip edip idareye geri dönüt veriyorduk. Idare de her hafta velileri arayıp değerlendirme yapıyordu." şeklinde açıklamıştır. Tüm bu tedbirlerin yanı sıra öğretmenler, canlı derslerin daha verimli olması için program geliştiricilerin de güvenlik sorunlarının çözümü için çalıştıklarından ve program alt yapısını geliştirdiklerinden bahsetmişlerdir.

\section{Uzaktan eğitimde kullanılan materyaller ve programlar}

Yapılan görüşmelerde öğretmenlere üçüncü soru olarak "2019-2020 eğitim öğretim yılı bahar döneminde matematik öğretimi için hangi öğretim materyallerini ve programlarını kullandınız? 20202021 eğitim öğretim yılı güz döneminde matematik öğretimi için hangi öğretim materyallerini ve programlarını kullanıyorsunuz? sorusu yöneltilmiştir. Öğretmenlerin verdikleri yanıtlardan elde edilen kod ve kategoriler Tablo 4' de sunulmuştur.

Tablo 4.

Uzaktan eğitim sürecinde kullanılan öğretim materyalleri ve programları

\begin{tabular}{|c|c|c|c|}
\hline Tema & Kategori & Kod & f \\
\hline \multirow{13}{*}{$\begin{array}{l}\text { Öğretim } \\
\text { Materyalleri }\end{array}$} & \multirow{6}{*}{$\begin{array}{l}\text { 2019-2020 eğitim öğretim yılı } \\
\text { bahar dönemi kullanılan } \\
\text { materyaller }\end{array}$} & $\begin{array}{l}\text { Kaynak dokümanlar (kitaplar, ders notları, } \\
\text { deneme sınavı, vb.) }\end{array}$ & 21 \\
\hline & & $\begin{array}{l}\text { Akıllı tahta uygulamaları (z kitap, akıllı defter, } \\
\text { Antropi Teach etkileşimli tahta programı vb.) }\end{array}$ & 10 \\
\hline & & Grafik tablet & 1 \\
\hline & & $\begin{array}{l}\text { Kaynak dokümanlar (kitaplar, ders notları, } \\
\text { deneme sınavı, vb.) }\end{array}$ & 25 \\
\hline & & $\begin{array}{l}\text { Akıllı tahta uygulamaları (z kitap, akıllı defter, } \\
\text { Antropi Teach etkileşimli tahta programı vb.) }\end{array}$ & 23 \\
\hline & & Sunum & 6 \\
\hline & \multirow{7}{*}{$\begin{array}{l}\text { 2020-2021 eğitim öğretim yılı } \\
\text { güz dönemi kullanılan } \\
\text { materyaller }\end{array}$} & Video & 11 \\
\hline & & Kendi ders videoları & 3 \\
\hline & & Somut materyaller & 6 \\
\hline & & EBA oyunları & 1 \\
\hline & & Beyaz tahta & 2 \\
\hline & & $\begin{array}{l}\text { Web } 2.0 \text { uygulamaları (Geogebra, matific, } \\
\text { quiziz vb.) }\end{array}$ & 4 \\
\hline & & Grafik/kalemli tablet & 7 \\
\hline Bilgi İletişim & & EBA & 17 \\
\hline Teknolojileri & & Zoom & 6 \\
\hline
\end{tabular}


2019-2020 eğitim öğretim yılı bahar dönemi kullanılan iletişim teknolojileri

2020-2021 eğitim öğretim yılı güz dönemi kullanılan iletişim teknolojileri
Whatsapp

6

Youtube 1

Perculus 1

EBA 17

Zoom

TeamLink

1

Whatsapp

7

DroidCam

Teknokent Uzaktan Eğitim Programı
1

1
17
18
1
7
1
1

Uzaktan eğitim sürecinde öğretmenlerin matematik öğretimi için kullandıkları öğretim materyalleri 2019-2020 bahar dönemi ve 2020-2021 güz dönemi olmak üzere iki kategoride incelenmiştir. Öğretmenlerin öğretim materyali olarak her iki dönem de daha çok kaynak dokümanları kullandıkları görülmektedir (bkz. Tablo 4). Bu kapsamda merkezi bir okulda görev yapan Ö8, ders kitabının pdf haline getirerek her iki dönemde kullandığını ve bu kitabın ekran paylaşımı yaparak canlı derslerini yürüttüğünü belirtmiştir. Benzer şekilde iki dönem de ders kitabından faydalanan ve varoş bir okulda görev yapan Ö16 ise "Öğrencilerimin ekonomik durumlarının iyi olmaması nedeniyle hem kendimin hem de öğrencilerimin elinde bulunan ders kitabını kullandım." ifadelerine yer vermiştir. Öğretmenlerin her iki dönem de kullandıkları diğer bir materyal ise kaynak kitaptır. Ö24, bahar döneminde sürecin geçici olduğunu düşünerek kaynak kitap kullanmadığını fakat sürecin uzaması üzerine güz döneminde çeşitli yayınların konu özetli fasiküllerini kullandığını dile getirmiştir. Bu yönde Ö7 ise geçen dönem kendi hazırladığı özet kâğıtlarını kullandığını belirterek "Bu dönem özet kâğıtları yerine EBA üzerinden ekran paylaşımı yapıyorum. Powerpoint sunumları kullanmaya başladım. Çalışma yaprakları hazırladım, EBA üzerinden pdf olarak paylaşıyorum." ifadelerine yer vermiştir. Diğer öğretmenlerden farklı olarak Ö25, bahar döneminde canlı dersler için hazırladığı kavram haritalarını kullandığını ve bu sayede öğrencilerin dersleri daha kolay anladığını belirtmiştir. Bir köy okulunda görev yapan Ö6 ise öğrencilerine deneme sınavları gönderdiğinden bahsederek "... 8. sınıflara giriyordum. Canlı ders yaptığım öğrenciler ile Whatsapp grupları oluşturup bu gruplarda öğrencilere pdf halinde deneme soruları attım." şeklinde açıklamıştır.

Akıllı tahta uygulamalarını (z kitap, akıllı defter, Antropi Teach etkileşimli tahta programı vb.) kullanan öğretmenlerin sayısının bahar dönemine göre güz dönemde daha fazla olduğu görülmüştür (bkz. Tablo 4). Görüşme yapılan öğretmenlerin neredeyse tamamı güz döneminde akıllı tahta uygulamalarını kullandığını belirtmiştir. Sadece iki öğretmen bu uygulamaları kullanmadığını belirtmiştir. Bu iki öğretmen ise evlerine beyaz tahta aldıklarını ve derslerini bu şekilde yürüttüklerini açıklamıştır. Ayrıca on beş öğretmen sadece güz döneminde z kitaplardan yararlandığını belirtirken sekiz öğretmen ise her iki dönemde de yararlandığını ifade etmiştir. Bununla ilgili olarak, merkezi bir okulda görev yapan Ö25, "Her iki dönemde de z kitaplar üzerinden derslerimi daha etkili bir şekilde işleyebiliyorum." ifadelerine yer vermiştir. Buna karşılık varoş bir okulda görev yapan Ö16 ise geçen dönem öğrencilerinin canlı derslere katılamadığını ancak bu dönem katılım sayısının fazla olduğunu belirtmiştir ve görüşmenin devamında "Bu dönem her konuda sürekli doküman bulmak zor olduğu için bilgisayara birkaç yayının z kitabını indirdim." ifadelerini kullanmıştır. Ayrıca beş öğretmen güz döneminde canlı dersler için kullandıkları programlarda mevcut olan etkileşimli tahtaları, kullanmaya başladıklarını belirtmişlerdir. Bu duruma ilişkin Ö23 görüşlerini şöyle dile getirmiştir: "Akıllı tahta programı ile dersleri anlatarak, daha güzel yazarak ögrencilerin dikkatli ders dinlemesini ve not tutmasını sağladık." Merkezi bir okulda görev yapan Ö20 ise her iki dönemde de etkileşimli tahtayı kullanarak canlı derslerini yürüttüğünü ifade etmiş ve bu konuda şu açıklamalarda bulunmuştur: "Matematik yazmadan olmuyor, işlem yapmak lazım. Mouse ile yazdığın doğru düzgün olmuyor. Bir sürü program denedim. Grafik tableti alınca etkileşimli tahtada düzgün bir şekilde yazmaya başladım, sınıfta tahtada ne anlatıyorsam aynısı gibi oldu." Ö20 matematik öğretimi için grafik veya kalemli tablet kullanmanın önemini vurgulayarak her iki dönem de kullandığını belirtmiştir. 
Bahar döneminden farklı olarak güz döneminde öğreticilerin kullandıkları farklı materyaller dikkat çekmektedir. Öğretmenlerin kendi ders videoları bu materyallere örnek olarak verilebilir. Üç öğretmen kendi ders anlatımlarını video kayıt altına alarak bu videoları EBA ya da Whatsapp üzerinden öğrencileriyle paylaştıklarından söz etmişlerdir. Bu anlamda on bir öğretmen ise hazır ders videolarını kullandıklarını belirtmişlerdir. İki öğretmen ders içeriğini zenginleştirmek için animasyonlu videolar kullanmayı tercih ederken altı öğretmen ise hazır konu sunumlarını tercih etmiştir. Bahar dönemden farklı olarak güz döneminde bazı öğretmenlerin Geogebra, Matific, Quiziz gibi web 2.0 uygulama araçlarını kullanmaya başladıkları göze çarpmaktadır. Öğretmenler, bu uygulama araçlarını kullanarak derslerini daha ilgi çekici ve zevkli hale getirdiklerini ileri sürmüşlerdir. Bazı öğretmenler ise bu teknolojik uygulamalar haricinde derslerinde kullanmak için somut materyaller aldıklarını ve güz döneminde bu materyalleri kullandıklarını belirtmişlerdir. Örneğin Ö7, matematik konularını daha somut bir şekilde öğrencilere anlatabilmek için çabaladığından ve yaz tatilinde somut materyaller aldığından bahsetmiştir: "...üç boyutlu cisimler aldım. Ayrıca telafi ... metre mezura ve cetvel alıp bunları derste kullandım. Öğrencilerin evinlerinde kendilerine materyal tasarlayıp hazırlamalarını istedim. Örneğin asal sayılar konusunu anlatırken her bir öğrencinin karton veya başka materyaller kullanarak Eratosthenes kalburu hazırlamaları için görevler verdim."

Öğretmenlerin kullandıkları bilgi iletişim teknolojileri incelendiğinde, EBA, Zoom ve Whatsapp uygulamalarının her iki dönemde kullanıldığı söylenebilir. Bununla birlikte 2019-2020 bahar döneminde en çok kullanılan canlı ders uygulaması EBA iken 2020-2021 güz döneminde ise Zoom olduğu dikkat çekmektedir. Bu durum özel okulların da Zoom programını kullanmayı tercih etmesinden kaynaklanabilir. Örneğin, özel okulda görev yapan Ö5, bahar döneminde Youtube programını kullanarak uzaktan eğitim verdiklerini ancak güz döneminde Zoom uygulamasını kullanmaya başladıklarını belirtmiştir. Benzer şekilde, özel okulda görev yapan Ö11 "Geçen dönem Perculus adlı programı kullandım. Bu dönem Teknokent uzaktan eğitim programını kullandım." ifadeleri ile her iki dönemde de farklı programlar kullandığını belirtmiştir. Bu dönemde ayrıca diğer programlardan farklı olarak TeamLink ve DroidCam programlarının da kullanıldığı tespit edilmiştir.

\section{Uzaktan eğitim sürecinde kullanılan öğretim yöntem ve teknikleri}

Yapılan görüşmelerde öğretmenlere dördüncü soru olarak "2019 2020 eğitim öğretim yılı bahar döneminde matematik öğretiminde hangi öğretim yöntem ve tekniklerini kullanarak uzaktan eğitimi sürdürdünüz? 20202021 eğitim öğretim yılı güz döneminde hangi öğretim yöntem ve tekniklerini kullanıyorsunuz?" sorusu yöneltilmiştir. Öğretmenlerin verdikleri cevaplara ait kod ve kategoriler Tablo 5' de verilmiştir.

Tablo 5.

Uzaktan eğitim sürecinde kullanılan öğretim yöntem, teknik ve stratejiler

\begin{tabular}{lll}
\hline Kategori & Kod & f \\
\hline & Düz anlatım & 17 \\
& Soru-cevap & 11 \\
& Problem çözme & 2 \\
2019-2020 eğitim-öğretim yılı bahar dönemi & Örnek olay & 1 \\
kullandıkları öğretim yöntem, teknik ve stratejiler & Buluş yoluyla öğretim & 1 \\
& Sunuş yoluyla öğretim & 5 \\
& Sesli okuma & 3 \\
& Tümevarım & 2 \\
& Aktif öğrenme & 1 \\
\cline { 2 - 3 } & Düz anlatım & 8 \\
& Soru-cevap & 21
\end{tabular}


2020-2021 eğitim-öğretim yılı güz dönemi kullandıkları öğretim yöntem, teknik ve stratejiler
Problem çözme 6

Örnek olay 1

Buluş yoluyla öğretim 7

Sunuş yoluyla öğretim 4

Araştırma inceleme yoluyla $\quad 1$

öğretim

Tümevarım 2

Aktif öğrenme 4

Probleme dayalı öğrenme 1

Eğitsel oyunlar 2

Balık kılçığı 1

Beyin firtınas1 7

Çalışma yaprakları 1

Proje temelli ögrenme 2

Gösterip yaptırma 5

Tartışma 2

Uzaktan eğitim sürecinde öğretmenlerin kullandıkları yöntem, teknik ve stratejiler incelendiğinde, öğretmenlerin 2019-2020 bahar döneminde en çok düz anlatım yöntemini kullandıkları görülmektedir (bkz. Tablo 5). Öyle ki öğretmenler ilk defa uzaktan öğretim süreci ile karşı karşıya kaldıkları için canlı derslerin sadece bu yöntem ile sürdürülebileceğini ileri sürmüşlerdir. Ancak 20202021 güz döneminde çoğu öğretmen, düz anlatım yöntemi yerine soru cevap yöntemini kullanmaya başlamıştır. Bununla ilgili olarak merkezi bir devlet okulunda görev yapan Ö2, bahar döneminde canlı ders uygulamalarının yeni başladığını, bu nedenle sadece düz anlatım yolu ile derslerini yürüttüğünü belirtmiştir. Aynı öğretmen güz dönemi için "Bu dönem daha çok sorular soruyorum. Soru cevap şeklinde canlı dersler devam ediyor. Sınıf listesini alıyorum soru sorarak herkesi derse katmaya çalışıyorum." ifadelerine yer vermiştir. Benzer şekilde merkezi bir devlet okulunda görev yapan Ö21 de bahar döneminde düz anlatım kullandığından bahsetmiş ve görüşmenin devamında güz döneminde daha çok soru cevap yöntemini kullandığını, bu şekilde etkileşimin arttığını ifade etmiştir. Bu yönde, varoş bir okulda görev yapan Ö16 ise her iki dönemde de düz anlatım yöntemini tercih ettiğini belirtmiştir. Zaman sıkıntısı yaşadığı için geçen dönem sadece düz anlatım yöntemini kullanan Ö14, "Geçen dönem sadece düz anlatım yapıyordum. Zaman yetişmediğinden... Bu dönem ders sayımız fazla olduğu için kameraları açıp soru cevap yapıyoruz, testleri ekranda paylaşıp birlikte çözüyoruz." ifadeleriyle bu dönem soru cevap tekniğini kullandığından söz etmiştir. Düz anlatım ve soru cevap yöntemlerini birlikte kullanan ve bir köy okulu öğretmeni olan Ö15 ise görüşlerini şu şekilde açıklamıştır: "iki dönemde de genelde düz anlatım yöntemini kullandım. Uzaktan eğitimde öğrenci ile iletişim yüz yüze eğitime göre daha zayıf olduğu için diğer yöntemleri kullanmanın zor olacağını düşünüyorum. Soru cevap tekniğini de oldukça fazla kullandım öğrencileri daha aktif kılmaya çalıştım."

Uzaktan eğitim sürecinin güz döneminde problem çözme yöntemini kullanan öğretmenlerin sayısı bahar dönemine göre artış göstermiştir (bkz. Tablo 5). Bununla ilgili olarak, merkezi bir devlet okulunda görev yapan Ö8 "...Bu dönem problem çözme metodunu da kullanıyorum." şeklinde görüşlerini ifade ederken özel okulda görev yapan Ö5 ise her iki dönemde de problem çözme yöntemini kullandığını belirtmiştir. Bu konuyla ilgili olarak şu açıklamaları yapmıştır: "Öğrencileri canlı derslerde aktif tutabilmek problemi önce gösteriyorum ve anlamalarını bekliyorum, sonra onlardan adım adım problemi çözmelerini istiyorum." Öte yandan merkezi bir devlet okulunda görev yapan Ö14 ise her iki dönemde canlı derslerinde örnek olay yöntemini ve araştırma inceleme yoluyla öğretim stratejisini kullandığından bahsetmiştir.

Tablo 5 incelendiğinde, güz döneminde buluş yolu ile öğretim yapan öğretmen sayısında belirgin bir şekilde artış olduğu ve sunuş yoluyla öğretim yapan öğretmen sayısının ise azaldığı görülmektedir. Ö1, her iki dönem için buluş yoluyla öğretim stratejisini kullandığını belirtirken Ö19 ise 
her iki dönemde de sunuş yoluyla öğretin stratejisini kullandığını ifade etmiştir. Yapılan görüşmelerde iki öğretmenin (Ö4 ve Ö11) hem bahar hem de güz döneminde bazı konuların öğretiminde tümevarım yöntemini tercih ettikleri görülmüştür. Ayrıca merkezi bir devlet okulunda görev yapan Ö7, uzaktan eğitim sürecinin ilk başladığı dönem tecrübesiz olduğu için farklı yöntem ve teknik kullanamadığını belirtmiş ancak güz döneminde farklı yöntemlerin uzaktan matematik öğretiminde kullanılabilirliğini test ettiğini, bu kapsamda çalışma yaprakları ile ders anlattığını, ayrıca probleme dayalı öğrenme yöntemini de kullandığını dile getirmiştir. Özel bir okulda görev yapan Ö11 ise "Geçen dönem genelde ögretmen merkezli yöntemler kullandım. Bu dönem sunuş yöntemine ek olarak proje temelli öğrenme kullanarak ders anlatımı yaptım." ifadelerine yer vermiştir.

2020-2021 güz döneminde öğretmenlerin kullandıkları farklı bir teknik ise beyin fırtınasıdır. Yedi öğretmen beyin fırtınası tekniğini güz döneminde kullanmaya başladıklarını belirtmiştir. Bu öğretmenlerden biri olan Ö14 “...Fakat bu dönem özellikle soru cevap ve beyin fırtınası kullanıyorum. Öğrencilerin katılımını sağlamak için beyin fırtınası oluşturarak her öğrencinin fikrini belirtmesini bekliyorum." şeklinde bu durumu anlatmıştır. Benzer şekilde Ö15 “...Bu dönem öğrencilere oldukça söz hakkı vererek, düşüncelerini alarak beyin fırtınası tekniğini kullandım." ifadelerine yer vermiştir. Ayrıca öğretmenlerin ifadelerinden bahar döneminden farklı olarak güz döneminde eğitsel oyunlar, tartışma, gösterip yaptırma yöntemlerini kullandıkları tespit edilmiştir.

\section{Tartışma, Sonuç ve Öneriler}

Bu çalışma, uzaktan eğitim sürecine katılan ortaokul matematik öğretmenlerinin süreç ile ilgili deneyimlerini yansıtmak amacıyla gerçekleştirilmiştir. Çalışma, ilk olarak matematik öğretmenlerinin uzaktan eğitim sürecinde çeşitli zorluklar yaşadıklarını ortaya koymaktadır. Benzer sonuçlara ulaşan konu ile ilgili birçok araştırmaya rastlanmaktadır (Kilit ve Pınar, 2021; Falowo, 2007; Gillies, 2008; Kim ve Bonk, 2006; Li, 2009). Görüşme yapılan öğretmenlerin uzaktan eğitim sürecinde yaşadıkları zorluklara yönelik belirttikleri görüşler doğrultusunda en fazla internet erişiminin olmamasından sıkıntı yaşadıkları tespit edilmiştir. Benzer bulgulara Can'ın (2020) çalışmasında rastlanmaktadır. Bu duruma dikkat çeken Can (2020), Türkiye'de eğitim sisteminin altyapı ve erişim gibi konularda güçlendirilmesinin gerekliliğini vurgulamıştır. Mevcut araştırmada kullanılan programın altyapısının yeterli olmaması, öğrenci ile doküman paylaşamama, öğrencinin mikrofonunun olmaması, öğrenciyi görememe ve öğrencinin anlayıp anlamadığını tespit edememe gibi sorunlara neden olmuştur. Benzer olarak Hebebci, Bertiz ve Alan (2020) çalışmalarında uzaktan eğitim faaliyetlerine yönelik altyapı sorunlarından ve donanım eksikliğinden bahsetmişlerdir. Farklı olarak bu çalışmada, varoş ve kırsal okullarda görev yapan öğretmenlerin alt yapı yetersizliği ve donanım eksikliği sorunlarıyla daha fazla karşılaştıkları tespit edilmiştir. Bu kapsamda dikkat çeken bir durum ise maddi yetersizlikler nedeniyle velilerin telefon, tablet ve bilgisayar gibi bilişsel iletişim araçlarını temin edememesi ve internete erişememesinden kaynaklanan sıkıntılar olmuştur. Uzaktan eğitimin altyapı ve ekipman ihtiyacı doğurduğunu belirten Lau, Yang ve Dasgupta (2020), bu durumun sosyoekonomik düzeyi düşük olan bireyler için daha fazla sorunlara yol açtığını ileri sürmüşlerdir.

Çalışma sonucunda matematik öğretmenlerinin uzaktan eğitimde, matematiksel içeriğe özgü olarak matematik öğretimini bilgisayar üzerinden yapma, matematiksel gösterimleri kullanma ve işlemler yapma gibi zorluklar yaşadıkları tespit edilmiştir. Ayrıca yapılan araştırmada görülmüştür ki matematiksel konuların birbiriyle bağlantılı olması nedeniyle öğrencilerin bir canlı derse katılamamaları bile diğer canlı derste anlatılan konuların öğrenilmesini etkilemektedir. Canlı ders süresinin matematik dersleri için yeterli olmaması ve matematiğin soyut bir yapısının olması da öğretmenlerin yaşadıkları matematik dersine özgü sorunlar arasında yer almaktadır. Öğretmenlerin uzaktan eğitim sürecinde okul yönetiminden kaynaklı sorunlar yaşadıkları da tespit edilmiştir. Bu durumlara örnek olarak ders saatlerinin uygun ayarlanmaması ve öğretmenlerin fikirlerinin yeterince alınmaması verilebilir. Bu 
çalışmaya paralel olarak Bakioğlu ve Çevik (2020) çalışmalarında uzaktan eğitimde öğretmenlerin, okul yönetiminin baskısına maruz kalma gibi çeşitli problemlere sahip olduklarını belirtmişlerdir.

Yapılan görüşmelerde, matematik öğretmenlerinin öğretici kaynaklı zorluklara ilişkin oldukça detaylı açıklamalar yaptıkları görülmüştür. Bu durum, öğretmenlerin sürece eleştirel bir bakış açısıyla yaklaştıklarını göstermektedir. Öğretmenler, pandemi sürecinde uzaktan eğitime uygun içerikler hazırlama, materyaller/dokümanlar bulma, yapmayı planladıkları etkinlikleri uygulama ve konuları yetiştirme gibi zorluklarla karşılaşmışlardır. Öğretmenlerin içerik hazırlama ve uygun öğretim materyalleri bulma sorunları, Karadağ ve Yücel'in (2020) çalışmalarında en düşük memnuniyet alanlarından biri olarak dijital içerik ve öğretim materyali çıkması sonucu ile paralellik göstermektedir. Bununla birlikte öğretmenlerin, öğrenci kaynaklı olarak mikrofon ve kamerayı etkinleştirmeme, dönüt vermeme, aynı anda konuşma gibi ders içi iletişimi etkileyen zorluklarla birlikte derse katılım yetersizliği, konuları tekrar etmeme, öğrenme zorluğu, ekranı gereksiz kullanma, derse karşı ilgisiz olma gibi zorluklar yaşadıkları da tespit edilmiştir. Elde edilen bu sonuçlar, Bakioğlu ve Çevik'in (2020) öğretmenlerin uzaktan eğitim boyunca yaşadıkları problemleri açıkladıkları araştırma sonuçlarını destekleyici niteliktedir. Bakioğlu ve Çevik (2020), öğretmenlerin internet sıkıntısı yaşadıklarını ve buna ek olarak öğrencilerin uzaktan eğitim derslerine katılımlarının düşük olması konusunda ve öğrencilerle etkili bir iletişim kurmada çeşitli problemler yaşadıklarını belirtmişlerdir. Bu çalışmada ise öğretmenlerin meslektaşlarıyla, öğrencilerle ve velilerle yeterince iletişim kuramama zorlukları ortaya çıkmıştır. Alan yazında uzaktan eğitim sürecinde iletişim eksikliğinin çeşitli sorunlara neden olduğunu belirten birçok araştırma bulunmaktadır (örn. Kilit ve Güner, 2020; Hebebci vd., 2020; Niemi ve Kousa, 2020).

Çalışmada ikinci adım olarak, öğretmenlerin uzaktan eğitim sürecinde yaşadıkları tüm bu zorluklara ilişkin aldıkları tedbirler araştırılmıştır. Öğreticilerin uzaktan eğitimin bahar döneminde yaşadıkları iletişim sorunlarını aşmak için iletişim yollarını artırmaya çalıştıkları görülmektedir. Başaran, Doğan, Karaoğlu ve Şahin'in (2020) uzaktan eğitimin birinci döneminde yaptıkları çalışmada, öğretmenöğrenci ve öğretmen-veli arasında iletişim sınılılıklarının olduğu ortaya çıkmıştır. Bu çalışmada öğretmelerin de iletişim sorunlarını fark ederek bu konuda tedbirler aldıkları görülmektedir. Öğretmenlerin teknolojideki yetersizliklerine vurgu yapan Sarı ve Nayır (2020), bunun uzaktan eğitimdeki zorluklardan biri olduğunu ifade etmiş ve öğretmenlerin bu sorunu çözmek için teknoloji becerilerini geliştirmelerini ise sorunların yarattığı eğitim fırsatları olarak vurgulamışlardır. Mevcut çalışma, bu bulguyu destekleyici nitelikte olup öğretmenlerin özellikle teknolojik zorlukların üstesinden gelebilmek için çaba gösterdiklerini ortaya koymaktadır. Bu bağlamda, öğretmenlerin kullandıkları programların içeriklerini öğrenmeye, matematiksel gösterim ve işlemler için grafik tablet kullanmaya ve daha farklı programlardan yararlanmaya çalıştıkları tespit edilmiştir. Ayrıca öğretmenlerin uzaktan eğitimde doküman/materyal eksikliğinde yaşadıkları zorluklar konusunda da uzaktan eğitimin güz döneminde tedbirler almaya çalıştıkları görülmüştür. Başaran vd. (2020) yaptıkları araştırmada uzaktan eğitim sürecinde farklı materyalleri kullanma sınırlılı̆ından bahsetmiş ve nitelikli bir öğrenme için uygun kaynakların kullanılması gerektiğini belirtmişlerdir. Bu kapsamda uzaktan eğitimin güz döneminde araştırmaya katılan öğretmenlerin eğitici animasyonlar ve videolar kullanmaya başladıkları, çalışma yaprakları hazırladıkları, kaynak kitaplar temin ettikleri, konu özetleri hazırladıkları, bilişsel eğitim materyalleri aldıkları tespit edilmiştir.

Uzaktan eğitimde öğreticilerin aldıkları tedbirlerden birisi de öğrencinin aktif katılımını sağlamadır. Öğrencinin daha iyi öğrenebilmesi için aktif olarak öğrenme deneyimine katılması, öğrenme sürecini ve etkinliklerini sahiplenmesi gerekir (Kyriacou, 1992). Öğretmenler, bu kapsamda öğrencinin derse katılıp katılmadığını takip etmiş, problemleri öğrencilerin defterlerine çözmelerini ve ders notu tutmalarını istemiş, öğrencilerin işlemlerini ve cevaplarını sözel olarak açıklamalarını sağlamışlardır. Bununla birlikte öğrenci katılımın artırmak için ödül ve pekiştireçler kullanmaya başlamışlardır. Öğretmenler sadece öğrencilerin canlı derslerde aktif olmalarını sağlamakla kalmayıp 
aynı zamanda ders dışı çalışmalarını da takip etmeye başlamışlardır. Böylece uzaktan eğitim sürecinde hem senkron hem de asenkron uygulamalar ile etkileşim düzeyini artırmaya çalışmışlardır. Ancak öğretmenlerin ifadelerinden daha çok öğretici-öğrenci ve öğrenci-içerik etkileşimleri üzerinde durdukları anlaşılmaktadır. Nitekim öğrenci-öğrenci etkileşimini dile getiren sadece bir öğretmen olmuştur. Oysa ki uzaktan eğitimde yüksek kalitede bir etkileşim düzeyi için öğrenciler arasında etkileşimin sağlanması önemlidir. Böylece öğrenciler web tabanlı bir sınıf ortamına ait olma duygusunu geliştirebilir (Palloff ve Pratt, 2001). Uzaktan eğitimde derslerin daha verimli olması ve yaşanan zorlukların giderilmesi amacıyla öğretmenlerin aldıkları bir diğer tedbir ise ders süresini daha etkin bir şekilde kullanmaktır. Bu anlamda çoğu öğretmenin z-kitaplar tercih ederek ders içeriğini zenginleştirmeye çalışmaları dikkate değerdir.

Bozkurt (2020a) çalışmasında uzaktan eğitimde velilerin daha fazla sorumluluk alması, öğrenme sürecini desteklemesi ve kolaylaştırması gerektiğini ifade etmiştir. Bununla paralel olarak yapılan araştırmada öğreticiler, uzaktan eğitim sürecinde velilerin de çeşitli tedbirler alarak öğrencilerin öğrenme süreçlerini desteklediklerini dile getirmişlerdir. Bu kapsamda veliler öğrencilerine akıllı telefon, tablet ve bilgisayar alarak ve telefonlarında var olan mevcut internet paketlerini genişleterek öğrencilere teknoloji desteği sağlamaya çalışmışlardır. Nitekim velilerin bu tedbirlerinin yeterli olmadığı ve eğitimde fırsat eşitsizliğinin devam ettiği tespit edilmiştir. Mevcut çalışma sonucunda özellikle varoş ve kırsal bölgelerdeki okullarda bu konuda kat edilmesi gereken çok yol olduğu söylenebilir. Yapılan çalışmada öğrenciyi takip etme ve uygun ortam hazırlama konularında da velilerin çaba gösterdikleri görülmekle birlikte bu çabaların daha çok merkezi okullarda görüldüğü sonucuna ulaşılmıştır. Buna rağmen öğretmen ile iletişime geçen ve okul ile iş birliği yapan velilerin sayısının yeterli olmadığı görülmüştür. Online öğrenmede öğrenci merkezli ve yapılandırmacı öğrenme teorisine dayanan bir model sunan Koohang, Smith ve Schreurs (2009), kendi öğrenme süreçlerinden öğrenenlerin sorumlu olduğunu vurgulamışlardır. Yapılan çalışmada, uzaktan eğitim sürecinde canlı derslerde yaşanan sorunların üstesinden gelebilmek için öğrencilerin de birtakım önlemler aldıkları sonucuna ulaşılmıştır. Bu süreçte öğrencilerin uzaktan eğitimin güz döneminde derslere hazırlık yaparak geldikleri ve daha fazla katılım sağladıkları, verilen görevleri yerine getirmek için daha gayretli oldukları öğretmenlerin ifadelerinden anlaşılmaktadır.

Okul yönetiminin, öğretmenleri matematikle ilgilenme çabalarında desteklemesi, öğretmenleri tutarlı bir şekilde anlaması, onlara yardımcı olmak için planlamalar ve uygulamalar yapması, tüm öğrenciler için matematiksel başarının temellerinin atılması açısından önemlidir (Leinwand, Huinker ve Brahier, 2014). Araştırmada matematik öğretmenleri ile yapılan görüşmelerde okul yönetiminin de uzaktan eğitimde matematiksel başarının artması için çeşitli tedbirler aldığı tespit edilmiştir. Bu yönde okul yönetiminin öğrenciler için EBA destek noktası oluşturarak öğrencilerin canlı derslere katılabilecekleri güvenli bir ortam sağlamaları, ders programlarını düzenleyerek ders sayılarını artırmaları, öğretmenlerle iş birliği içinde çalışmaları dikkate değer bir bulgudur. Ancak varoş ve kırsal bölgelerde bulunan okullarda veliyle iletişim kurmak için okul yönetimine daha fazla iş düştüğü söylenebilir.

Uzaktan eğitim sürecinde öğretmenlerin matematik öğretimi için her iki dönemde çeşitli kaynak dokümanları kullandıkları ancak varoş okullarda görev yapan öğretmenlerin daha çok matematik ders kitaplarından faydalandıkları belirlenmiştir. Bu durum, varoş okullarda öğretim gören öğrencilerin ellerinde sadece ders kitaplarının olmasından kaynaklanabilir. Çınar vd. (2011) yaptıkları çalışmada uzaktan eğitime yönelik olarak anlık sesli ve görüntülü etkileşim sunan, dosya ve masaüstü paylaşımı yapabilen eşzamanlı sanal sınıf araçları kullanılması gerektiğini ifade etmişlerdir. Yapılan araştırmada akıllı tahta uygulamalarını (z kitap, akıllı defter, Antropi Teach etkileşimli tahta programı vb.) ve daha kolay etkileşim imkânı veren grafik/kalemli tabletleri kullanan öğretmenlerin sayısının bahar dönemine göre güz dönemde daha fazla olduğu görülmüştür. Ayrıca bahar döneminden farklı olarak güz döneminde öğreticilerin kullandıkları farklı materyaller dikkat çekmektedir. Öğretmenlerin 
kendilerinin hazırladıkları ders videoları, animasyonlu videolar ve Geogebra, Matific, Quiziz gibi Web 2.0 uygulama araçlarını kullanmaya başladıkları göze çarpmaktadır. Ancak bu uygulamaları kullanan öğretmen sayısının oldukça az olması ve daha çok özel okulda görev yapan öğretmenler tarafından kullanılması, öğretmenlerin uzaktan eğitimde oldukça işlevsel olan Web 2.0 uygulama araçları hakkında yeterince bilgiye sahip olmadıklarını göstermektedir.

Dikkate değer bir başka bulgu ise kent merkezinde görev yapan öğretmenlerin güz döneminde yürüttükleri canlı derslerin verimliliğini artırmak için uygun materyal ve doküman arayışlarında olmaları buna karşııık kırsal ve varoş okullarda görev yapan öğretmenlerin ise internet sorunlarını çözerek derse katılımı artırmaya yönelik ek çabalar sarf etmeleridir. Bu durum sosyo-ekonomik eşitsizliklerin öğreticilerin aldıkları tedbirleri yönlendirmesi olarak değerlendirilebilir. Bozkurt (2020b) çalışmasında uzaktan eğitimde planlama yapılmadan öğrencilerin sahip olduğu olanaklar düşünülmeden yapılan uygulamalarda sosyal eşitsizliklerin ortaya çıkabileceğini belirtmiştir. Öğretmenlerin uzaktan eğitim sürecinde kullandıkları yöntem, teknik ve stratejiler incelendiğinde, öğretmenlerin bahar döneminde en çok düz anlatım yöntemini kullandıkları güz döneminde ise düz anlatım yöntemi yerine soru cevap yöntemini kullanmaya başladıkları tespit edilmiştir. Bu bulgu Başaran vd. (2020) çalışma sonuçlarını destekleyici niteliktedir. Ayrıca öğretmenlerin güz döneminde uzaktan eğitim deneyimlerinin artmasıyla birlikte farklı öğretim yöntem (eğitsel oyun, tartışma, gösterip yaptırma) ve tekniklerini (balık kılçığı ve beyin fırtınası) kullanmaya başladıkları söylenebilir.

Genel olarak, çalışmanın sonucunda kırsal, varoş ve kent merkezinde görev yapan öğretmenlerin uzaktan eğitimde çeşitli zorluklarla karşılaştıkları ve bunların üstesinden gelebilmek için çevresel koşullara uygun önlemler alabildikleri ortaya çıkmıştır. Öyle ki alınan önlemlerin devlet okullarında ve özel okullarda görev yapan öğretmenler arasında bile değişiklik gösterdiği söylenebilir. Özellikle varoş ve kırsal okullarda görev yapan öğretmenlerin ve okul yöneticilerinin uzaktan eğitim sürecinde fırsat eşitsizliğinden ve alt yapı yetersizliğinden dolayı oldukça zorlandıkları ve bu yönde imkanları doğrultusunda çabaladıkları görülmüştür. Bu durum uzaktan eğitim sisteminde fırsat eşitliği ve alt yapı konularında iyileştirici çalışmalar yapılması gerekliliğini ortaya koymaktadır. Öte yandan öğretmenlerin ilk defa karşılaştıkları uzaktan eğitim sürecine ilişkin deneyimlerinin artması ile birlikte bu sürecinin kalitesini artırmak amacıyla farklı yöntem ve teknikleri kullanmaya başladıkları ve bu konuda kendilerini her geçen gün geliştirdikleri söylenebilir. Buna karşılık öğretmenlerin yeni teknolojik araçları derslerinde etkin bir şekilde kullanamamaları, özellikle Web 2.0 uygulama araçları hakkında yeterince bilgiye sahip olmadıklarını göstermektedir. Bunun için Web 2.0 uygulama araçlarının kullanımına yönelik online eğitimler düzenlenebilir. Ayrıca uzaktan eğitimde derslerin daha verimli olması ve yüksek kalitede etkileşimin sağlanması için öğretici-öğrenci ve öğrenci-içerik etkileşimlerine ek olarak öğrenci-öğrenci etkileşimlerine de önem verilmelidir. Dolayısıyla bu sonuçlar göz önünde bulundurularak uzaktan eğitimin kalitesini artırmak için ne tür öğretimsel faaliyetler yürütülebileceği planlanabilir. Bu ise uzaktan eğitim sistemi konusunda daha fazla araştırma yapılması ihtiyacını ortaya koymaktadır. Matematik öğretmenlerinin uzaktan eğitim deneyimlerini ortaya koyan bu nitel çalışmanın, öğretmenlerin yaşadıkları zorlukların giderilmesi ve aldıkları tedbirleri destekleyici faaliyetlerin planlanması yönünde olumlu bir etki göstereceği düşünülmektedir. Uzaktan eğitimin yeni bir yaşam tarzında kaçınılmaz bir eğitim modeli olduğu düşünüldüğünde uygulanacak öğretimsel faaliyetlerin etkili olup olmadığını belirlemeye yönelik deneysel araştırmalar yürütülebilir. 


\section{Kaynakça}

Ağır, F. (2007). Özel okullarda ve devlet okullarında çalışan ilköğretim öğretmenlerinin uzaktan eğitime karşı tutumlarının belirlenmesi. (Yayımlanmamış yüksek lisans tezi). Balıkesir Üniversitesi, Fen Bilimleri Enstitüsü, Balıkesir.

Bakioğlu, B. ve Çevik, M. (2020). COVID-19 Pandemisi sürecinde fen bilimleri öğretmenlerinin uzaktan eğitime ilişkin görüşleri. Turkish Studies, 15(4), 109-129. doi: 10.7827/TurkishStudies.43502

Barış, M. F. ve Çankaya, P. (2016). Akademik personelin uzaktan eğitim hakkındaki görüşleri. International Journal of Human Sciences, 13(1), 399-413.

Başaran, M., Doğan, E., Karaoğlu, E. ve Şahin, E. (2020). Koronavirüs (covid-19) pandemi sürecinin getirisi olan uzaktan eğitimin etkililiği üzerine bir çalışma. Academia Eğitim Araştırmaları Dergisi, 5(2), 368-397.

Bayburtlu, Y.S. (2020). Covid-19 pandemi dönemi uzaktan eğitim sürecinde öğretmen görüşlerine göre Türkçe eğitimi. Turkish Studies, 15(4), 131-151.

Berge, Z. L. (1995). The role of the online instructor/facilitator. Educational Technology, 35(1), 22-30.

Billings, D. M., Connors, H. R. ve Skiba, D. J. (2001). Benchmarking best practices in Web-based nursing courses. Advances in Nursing Science, 23, 41-52.

Bozkurt, A. (2020a). Koronavirüs (covid-19) pandemi süreci ve pandemi sonrası dünyada eğitime yönelik değerlendirmeler: Yeni normal ve yeni eğitim paradigması. Açıköğretim Uygulamaları ve Araştırmaları Dergisi, 6(3), 112-142.

Bozkurt, A. (2020b). Koronavirüs (covid-19) pandemisi sırasında ilköğretim öğrencilerinin uzaktan eğitime yönelik imge ve algıları: Bir metafor analizi. Uşak Üniversitesi Eğitim Araştırmaları Dergisi, 6(2), 1-23.

Can, E. (2020). Coronavirüs (covid-19) pandemisi ve pedagojik yansımaları: Türkiye'de açık ve uzaktan eğitim uygulamaları. Açıköğretim Uygulamaları ve Araştırmaları Dergisi. 6(2), 11-153.

Cabı, E. ve Ersoy, H. (2017). Yükseköğretimde uzaktan eğitim uygulamalarının incelenmesi: Türkiye örneği. Yükseköğretim ve Bilim Dergisi, 7(3), 419-429.

Chang, G. C. ve Satako, Y. (2020, Mart). How are countries addressing the Covid-19 challenges in education? A snapshot of policy measures. [Blog yazısI]. Erişim adresi (10.10.2020): https://gemreportunesco.wordpress.com/2020/03/24/how-are-countries-addressing-the-covid-19challenges-in-education-a-snapshot-of-policy-measures/

Creswell, J. W. (2013). Qualitative inquiry \& research design. (3 bs.). Thousand Oaks, CA: SAGE

Çınar, M., Tüzün, H., Yıldırım, D., Akıncı, A., Kalaycı, E., Bilgị̧, H. G. ve Yüksel, Y. (2011, Şubat). Uzaktan eğitimde kullanılan eşzamanlı sanal sınıf araçlarının karşılaştırılması. Akademik Biliş̧im Konferansında sunulan bildiri, (s. 451-456). İnönü Üniversitesi, Malatya. Erişim adresi (14.10.2020): http://yunus.hacettepe.edu.tr/ htuzun/html/academic/cinar_tuzun_AB11.pdf

Demir, E. (2014). Uzaktan eğitime genel bir bakış. Dumlupınar Üniversitesin Sosyal Bilimler Dergisi, 39, 203-212.

Dennen, V. P., Darabi, A. A. ve Smith, K. J. (2007). Instructor-learner interaction in online courses: The relative perceived importance of particular instructor actions on performance and satisfaction. Distance Education, 28, 65-79.

Dougiamas, M. (2000, February). Improving the effectiveness of tools for the internet-based education. 9th. Annual Teaching Learning Forum, Curtin University of Technology, USA. Erişim adresi (18.11.2020): https://litec.curtin.edu.au/events/conferences/tlf/tlf2000/dougiamas.html

Falowo, R. O. (2007). Factors impeding implementation of web-based distance learning. AACE Journal, 15(3), 315338.

Gillies, D. (2008). Student perspectives on video-conferencing in teacher education at a distance. Distance Education, 29(1), 107-118.

Gürer, M. D., Tekinarslan, E. ve Yavuzalp, N. (2016). Çevrimiçi ders veren öğretim elemanlarının uzaktan eğitim hakkındaki görüşleri. Turkish Online Journal of Qualitative Inquiry (TOJQI), 7(1), 47-78.

Hillman, D. C. A., Willis, D. J. ve Gunawardena, C. N. (1994). Learner-interface interaction in distance education: An extension of contemporary models. American Journal of Distance Education, 8(2), 30-42.

Hebebci, M. T., Bertiz, Y. ve Alan, S. (2020). Investigation of views of students and teachers on distance education practices during the coronavirus (covid 19) pandemic. International Journal of Technology in Education and Science. 4(4), 2651-5369.

İşman, A. (2011). Uzaktan eğitim (4. Bs.). Ankara: Pegem Akademi. 
Jansen, D. G. ve Lewis, W. B. (1996). Creating high levels of interaction in distance education courses. ATEA Journal, 24(1), 8-9.

Karaman, S. ve Karabey, S. (2020). Uzaktan öğretimde canlı ders uygulama ilkeleri ve örnekleri. S. Karaman ve E. Kurşun (Ed.), Canlı derslerin genel özellikleri ve işleyişi (s. 1-10) içinde. Erzurum: Atatürk Üniversitesi Yayınevi.

Karadağ, E. ve Yücel, C. (2020). Yeni tip korona virüs pandemisi döneminde üniversitelerde uzaktan eğitim: lisans öğrencileri kapsamında bir değerlendirme çalışması. Journal of Higher Education (Turkey), 10(2), 181192.

Kaya, Z. (2006). Öğretim teknolojileri ve materyal geliştirme. Ankara: Pegem Akademi.

Kearsely, G. (1995). The nature and value of interaction in distance learning. Distance Education, 12, 83-92.

Kilit, B. ve Güner, P. (2021). Matematik derslerinde web tabanlı uzaktan eğitime ilişkin matematik öğretmenlerinin görüşleri. Anemon Muş Alparslan Üniversitesi Sosyal Bilimler Dergisi, 9(1) 85-102.

Kim, K. J. ve Bonk, C. J. (2006). The future of online teaching and learning in higher education. Educause quarterly, 29(4), 22-30.

Koohang, A., Riley, L., Smith, T. ve Schreurs, J. (2009). E-learning and constructivism: From theory to application. Interdisciplinary Journal of E-Learning and Learning Objects, 5(1), 91-109.

Krippendorff, K. (2018). Content analysis: An introduction to its methodology. (4 bs.). SAGE Publications.

Kyriacou, C. (1992). Active learning in secondary school mathematics. British Educational Research Journal, 18(3), 309-318.

Lau, J., Yang, B. ve Dasgupta, R. (2020, 12 March). Will the coronavirus make online education go viral? Times Higher Education. Erişim adresi (21.10.2020): https://www.timeshighereducation.com/features/willcoronavirus-make-online education-go-viral

Lehman, R. M. ve Conceição, S. C. (2010). Creating a sense of presence in online teaching: How to "be there" for distance learners. San Francisco, CA: John Wiley \& Sons.

Leinwand, S., Huinker, D. ve Brahier, D. (2014). Principles to action: Mathematics programs as the core for student learning. Mathematics Teaching in the Middle School, 19(9), 516-519.

$\mathrm{Li}, \mathrm{X}$. (2009). Review of distance education used in higher education in China. Asian Journal of Distance Education, $7(2), 22-27$.

Lin, C. Y. (2020). Social reaction toward the 2019 novel coronavirus (COVID-19). Social Health Behavior, 3, 1-2.

Miles, M, B. ve Huberman, A. M. (1994). Qualitative data analysis: An expanded sourcebook. (2 bs.). Thousand Oaks, CA: Sage.

Moore, M. G. (1989). Three types of interaction. The American Journal of Distance Education, 3(2), 1-6.

Moore, M.G. ve Kearsley, G. (2011). Distance education: A system view of online learning. (3 bs.). Boston, MA: Wadsworth Publishing.

Moustakas, C. (1994). Phenomenological research methods. Thousand Oaks, CA: Sage.

Niemi, H. M. ve Kousa, P. (2020). A case study of students' and teachers' perceptions in a Finnish high school during the COVID pandemic. International Journal of Technology in Education and Science (IJTES), 4(4), 352-369.

Osmanoğlu, A. E. (2020). Social studies teachers' views on televisional distance education. Journal of Current Researches on Educational Studies, 10(1), 67-88.

Palloff, R. M. ve Pratt, K. (2001). Lessons from the cyberspace classroom: The realities of online teaching. San Francisco: Jossey-Bass.

Romiszowski, A. (2004). How's the e-learning baby? Factors leading to success or failure of an educational technology innovation. Educational Technology, 44(1), 5-27.

Sarı, T. ve Nayır, F. (2020). Pandemi dönemi eğitim: sorunlar ve fırsatlar. Turkish Studies, 15(4), 959-975. https://dx.doi.org/10.7827/TurkishStudies.44335

Schlosser, L. A. ve Simonson, M. (2009). Distance education: Definition and glossary of terms. (3 bs.). Charlotte, NC: Information Age.

Smith, P. L. ve Dillon, C.L. (1999). Comparing distance learning and classroom learning: Conceptual considerations. American Journal of Distance Education, 13(2), 6-23. https://www.learntechlib.org/p/89072/.

Şahin İzmirli, Ö. ve Mısırlı, Z. A. (2018, Ekim). Öğretim elemanlarının uzaktan eğitime ilişkin metaforik algıları. Uluslararası Necatibey Eğitim ve Sosyal Bilimler Araştırmaları Kongresinde sunulan bildiri (UNESAK 2018), (s. 177). Balıkesir, Türkiye. Erişim adresi (01. $11 . \quad 2020)$ : http://unesak.com/UNESAK\%202018\%20özet\%20kitabı.pdf 
Thurmond, V. ve Wambach, K. (2004). Understanding interactions in distance education: A review of literature. International Journal of Instructional Technology and Distance Learning. 1(1), 9-26.

Üstün, Ç. ve Özçiftçi, S. (2020). COVID-19 Pandemisinin sosyal yaşam ve etik düzlem üzerine etkileri: Bir değerlendirme çalışması. Anadolu Kliniği Tıp Bilimleri Dergisi, 25, 142-153.

Yıldırım, A. ve Şimşek, H. (2016). Sosyal bilimlerde nitel araştırma yöntemleri. (10. bs.). Ankara: Seçkin yayıncılık. 